Int. J. Dev. Biol. 51: 447-461 (2007)

doi: $10.1387 / \mathrm{ijdb} .072327 \mathrm{as}$

\title{
The preplacodal region: an ectodermal domain with multipotential progenitors that contribute to sense organs and cranial sensory ganglia
}

\author{
ANDREA STREIT* \\ Department of Craniofacial Development, King's College London, Guy's Campus, London, UK
}

\begin{abstract}
The otic primordium belongs to a group of related structures, the sensory placodes that contribute to the paired sense organs - ear, eye and olfactory epithelium - and to the distal parts of the cranial sensory ganglia. Recent evidence suggests that despite their diversity, all placodes share a common developmental origin and a common molecular mechanism which initiates their formation. At the base of placode induction lies the specification of a unique "placode field", termed the preplacodal region and acquisition of this "preplacodal state" is required for ectodermal cells to undergo otic development. Here I review the molecular mechanisms that sequentially subdivide the ectoderm to give rise to the placode territory.
\end{abstract}

KEY WORDS: BMP, ear, ectoderm, epibranchial, eye, FGF, olfactory epithelium, sensory placodes, Wnt

\section{Introduction}

The adult vertebrate inner ear is sophisticated both in structure and function. Responsible for the perception of sound, balance and acceleration it comprises the semicircular canals, cochlea and endolymphatic duct and a large variety of different cell types including hair and supporting cells within the sensory patches. It is therefore remarkable that during development it arises from a simple epithelium, the otic placode, which is first visible around the 10 somite stage next to rhombomeres 5 and 6 of the hindbrain (Bancroft and Bellairs, 1977; Verwoerd, et al., 1981; Haddon and Lewis, 1996; Schlosser and Northcutt, 2000). Subsequently, the placode invaginates and separates from the surface ectoderm to form the otic vesicle, which then undergoes complex morphogenetic events to generate the mature inner ear. However, already long before the otic placode is morphologically distinct, patterning events in the ectoderm are well under way to restrict its formation to the ectoderm next to the future hindbrain and to determine the position of future otic cells in relation to precursors for other sensory placodes (for review: Streit, 2004; Bailey and Streit, 2006; Schlosser, 2006). In particular, classical and recent evidence has highlighted the importance of a unique territory in the head ectoderm that contains precursors for all cranial placodes, including the otic primordium and has therefore been named the preplacodal region (PPR; Jacobson, 1963; for review: Streit, 2004; Bailey and Streit, 2006; Schlosser, 2006). The acquisition of a 'preplacodal state' appears to be a prerequisite for ectoder- mal cells to become specified as otic precursors (Martin and Groves, 2006).

\section{The preplacodal region - a common ground state for all sensory placodes}

Cranial placodes form an apparently disparate group of structures that contribute to the eye, ear, olfactory epithelium and lateral line (fish, amphibians) and to the distal portions of the cranial sensory ganglia (Fig. 1A). Their derivatives in the adult vary largely in structure, function and in the cell types they produce ranging from simple lens fibre cells to sensory receptor cells like hair cells in the ear or olfactory receptor cells in the nasal epithelium. Their development and derivatives have recently been reviewed extensively elsewhere (Baker and Bronner-Fraser, 2001; Streit, 2004; Schlosser, 2006). Despite their apparent differences they share similarities during early development: all placodes form columnar epithelia next to the neural tube, contain cells that undergo epithelial-mesenchymal transition, contribute to the cranial sensory nervous system and are neurogenic with the exception of the lens. In addition, recent evidence suggests that they initially share a common developmental programme before they diversify and acquire unique identity (see below for discussion; Bailey, et al., 2006) and that cells must go through a

Abbreviations used in this paper: BMP, bone morphogenetic protein; FGF, fibroblast growth factor; PPR, preplacodal region. 
'preplacodal state' before they can respond to placode inducing signals (Martin and Groves, 2006). A continuous placode territory, where all placode precursors reside, can first be identified at neurula stages and is defined by the expression of unique set of molecular markers as well as by common properties of all cells contained in it (Jacobson, 1963; Kozlowski, et al., 1997; Streit, 2002; Bhattacharyya, et al., 2004; Schlosser and Ahrens, 2004; Bailey, et al., 2006; for review: Streit, 2004; Bailey and Streit, 2006; Schlosser, 2006). Here, I review how sequential subdivision of the ectoderm leads to the establishment of the preplacodal region, its functional relevance to placode development and to otic induction in particular and how it becomes subdivided to generate precursors for different placodes.

\section{Subdivision of the ectoderm: changes in gene expres- sion and the segregation of cell fates}

Like neural, neural crest and epidermal precursors, placodal cells are ectodermal derivatives. How and when do cells of different fates segregate? Fate map analysis in zebrafish, Xenopus, mouse and chick show that around the time of gastrulation the ectoderm is roughly subdivided into neural and non-neural ectoderm, although a large intermediate region exists in which both fates overlap (Keller, 1975; Keller, 1976; Tam, 1989; Kimmel, et al., 1990; Garcia-Martinez, et al., 1993; Hatada and Stern, 1994; Lawson, 1999; Fernandez-Garre, et al., 2002). This broad separation of cells with different fates is reflected by gene expression (Fig. 2A). Pre-neural markers such as ERNI(chick; Streit, et al., 2000), Sox3(Penzel, et al., 1997; Rex, et al., 1997; Kudoh, et al., 2004), Geminin (Xenopus; Kroll, et al., 1998) and SoxD (Xenopus; Mizuseki, et al., 1998) are concentrated in the future neural domain and gradually decrease towards the non-neural ectoderm, while genes like Gata2, Gata3, DIx-3, -5, Foxil or Foxi3, BMP4 and Msx1 show the opposite expression pattern (Papalopulu and Kintner, 1993; Akimenko, et al., 1994; Streit, et al., 1998; Pera, et al., 1999; Sheng and Stern, 1999; Streit and Stern, 1999; Luo, et al., 2001; Streit, 2002; Liu, et al., 2003; Solomon, et al., 2003; Ohyama and Groves, 2004; MatsuoTakasaki, et al., 2005). At this stage, precursors for different placodes, including the otic, are still widely dispersed and intermingled with future neural, epidermal and neural crest cells in the chick (Garcia-Martinez, et al., 1993; Hatada and Stern, 1994; Streit unpublished), although a more restricted distribution has been reported in zebrafish (Kozlowski, et al., 1997).

With the formation of the definitive neural plate (Fig. 2B), neural specific genes like Sox2become up-regulated (Rex, et al., 1997; Kishi, et al., 2000), while pre-neural markers either become confined to a broad band of ectoderm surrounding the neural plate (ERN) or remain expressed in both domains (Sox3, Geminin). Likewise, some non-neural markers become upregulated in (e.g. D/x and Gata) or confined to (e.g. Foxil) the ectoderm next to the neural plate. Thus, at early neurula stages a contiguous stripe of ectoderm coexpresses pre-neural and non-neural ectoderm markers and has therefore been termed the 'border' (Streit and Stern, 1999; McLarren, et al., 2003; Woda, et al., 2003; Meulemans and Bronner-Fraser, 2004). Within the border region precursors for neural, neural crest, epidermis and placodes remain interspersed (Kozlowski, etal., 1997; Streit, 2002; Bhattacharyya, etal., 2004).

Shortly thereafter, members of the Six and Eya families of nuclear factors begin to be expressed in a horseshoe-shaped domain surrounding the rostral neural plate from fore- to hindbrain levels (Fig. 2C) (Mishima and Tomarev, 1998; Esteve and Bovolenta, 1999; Sahly, et al., 1999; Kobayashi, et al., 2000; Pandur and Moody, 2000; McLarren, etal., 2003; Bessarab, etal., 2004; Schlosser and Ahrens, 2004; Litsiou, et al., 2005). Simultaneously, precursors for all placodes become concentrated in the Six/Eyat territory to form a contiguous, unique domain: the preplacodal region (Streit, 2002; Bhattacharyya, etal., 2004) (Fig. 1B). Unlike other factors that have a more widespread expression in the ectoderm (D/x3/5and Gata3), Six1, Six4, Eya1and/or Eya2
A

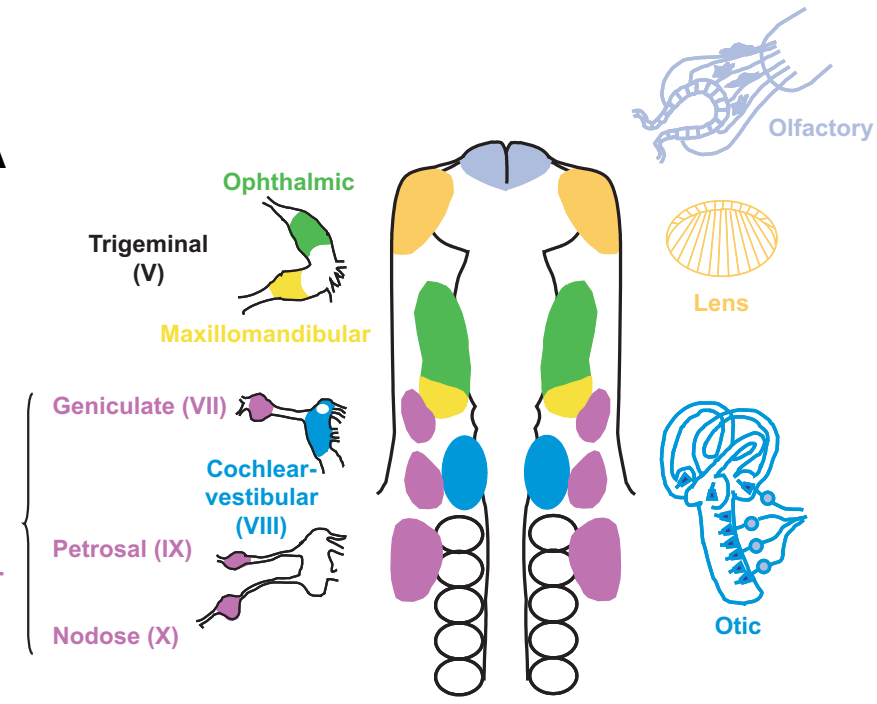

B

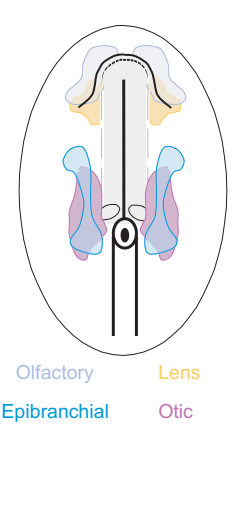

C

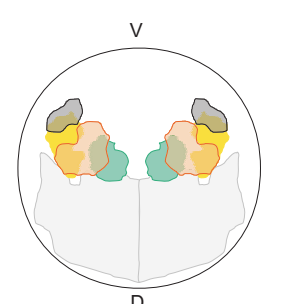

D

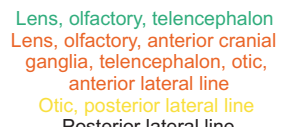

Lens, olfactory, telencephalon
Lens, olfactory, anterior cranial anterior lateral line
and Posterior lateral line
D

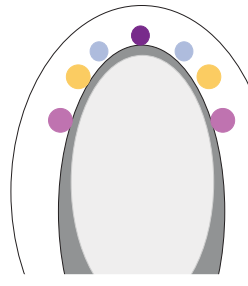

Adenohypopysheal Otic

Fig. 1. Position of sensory placodes at the $\mathbf{1 0}$-somite and fate maps at late gastrula and neural plate stages. (A) Schematic representation of the sensory placodes and their derivatives at the 10 somite stage in the chick embryo (after D'Amico-Martel and Noden, 1983; Bhattacharyya, et al., 2004). (B) Fate map of a 1-somite stage chick embryo (after Streit, 2002; Bhattacharyya, et al., 2004). Grey, neural plate. (C) Fate map of a zebrafish embryo at 50\% epiboly (modified from Kozlowski, et al., 1997); grey, neural plate, (Woo and Fraser, 1995). (D)Fate map of salamander embryo (Ambystoma) at neural plate stages (modified from Carpenter, 1937). Light grey, neural plate; dark grey, neural folds. 
are exclusively expressed in the preplacodal region.

Around the same time, neural crest specific genes such as Snail2, FoxD3or Sox10begin to be expressed in a thin line along most of the neural plate (except its most rostral part, where no neural crest cells are generated; Couly and Le Douarin, 1985; Couly and Le Douarin, 1987). Although some overlap between neural crest and placode precursors is still observed at this stage in chick, both fates are completely segregated by the $4-5$ somite stage, when the neural plate has begun to fold and neural folds are morphologically obvious (Fig. 2D) (Streit, 2002; Bhattacharyya, et al., 2004). Thus, by late neurula stages, the preplacodal region is molecularly and cellularly distinct from other ectodermal derivatives.

\section{Transcription factors that position the neural plate border}

As outlined above, a number of transcription factors are coexpressed at the border of neural and non-neural ectoderm before the onset of definitive neural crest and placode markers and are therefore likely to function upstream of preplacodal genes. Indeed, some of these have been implicated in controlling the position of the border and appear to be required for the specification of border derivatives. Msx1 is a direct mediator of BMP signalling and as such functions in promoting epidermal and repressing neural character during early stages of Xenopus development, thereby positioning the border between both tissues (Suzuki, et al., 1997; Feledy, et al., 1999; Phillips, et al., 2006). However, at late gastrula/early neurula stages Msx1 is more specifically involved in neural crest cell formation; it is both required for and sufficient to induce neural crest cells at the border of the neural plate (Tribulo, et al., 2003; Monsoro-Burq, et al., 2005; Khadka, et al., 2006; Phillips, et al., 2006). Like Msx1, members of the DIx family also counteract neural plate formation, but in addition both seem to play antagonistic roles during the specification of neural crest and placode precursors. Misexpression of DIx5, DIx3 or constitutively active DIx3 represses neural and neural crest cells, while promoting the expression of preplacodal Six1 and -4 (Luo, et al., 2001; McLarren, etal., 2003; Woda, et al., 2003). In contrast, overexpression of dominant negative DIx3 shifts the neural plate border laterally or results in a complete loss of preplacodal gene expression (Woda, et al., 2003), while in zebrafish, knockdown or deletion of $d / x 3 b$ and $-4 b$ (b380 mutants) leads to a severe reduction of olfactory, trigeminal and otic placodes (Solomon and Fritz, 2002; Kaji and Artinger, 2004). However, when MsxB, C and E function is blocked in b380 mutants, placode development is restored indicating that in the absence of DIx function Msx proteins repress placode formation (Phillips, et al., 2006). Thus, DIx protein function is required for normal placode formation, but its activity in the border region opposes Msx1 function. Since their expression partially overlaps fine tuning of their function maybe achieved through direct protein-protein interaction: Dlx and Msx proteins can form heterodimers that block their function as transcriptional activator or repressor (Zhang, et al., 1997). Thus, on cellular level relative expression levels of DIx and Msx proteins may determine cell fate choices.

The winged helix transcription factor Foxil has mainly been studied in relation to its function in early otic development. However, recent evidence indicates that it may have an even earlier function in positioning the border between neural and nonneural ectoderm. In Xenopusand fish, Foxil is initially expressed widely, but then becomes rapidly confined to a stripe of ectoderm surrounding the neural plate (Solomon, et al., 2003; MatsuoTakasaki, et al., 2005; Hans, et al., 2007). A similar expression is observed in mouse for Foxi3(Ohyama and Groves, 2004). In fish, its requirement for otic and epibranchial placode specification has been demonstrated in Foxil mutants (foo/foo, hearsay and no soul; Lee, et al., 2003; Nissen, et al., 2003; Solomon, et al., 2003), while other sensory placodes have not been investigated in detail. Two recent studies suggest that both Foxil and DIx $3 \mathrm{~b}$ are required in ectodermal cells to respond to the otic inducing factor FGF8 (Hans, et al., 2004; Hans, et al., 2007): misexpression of FGF8

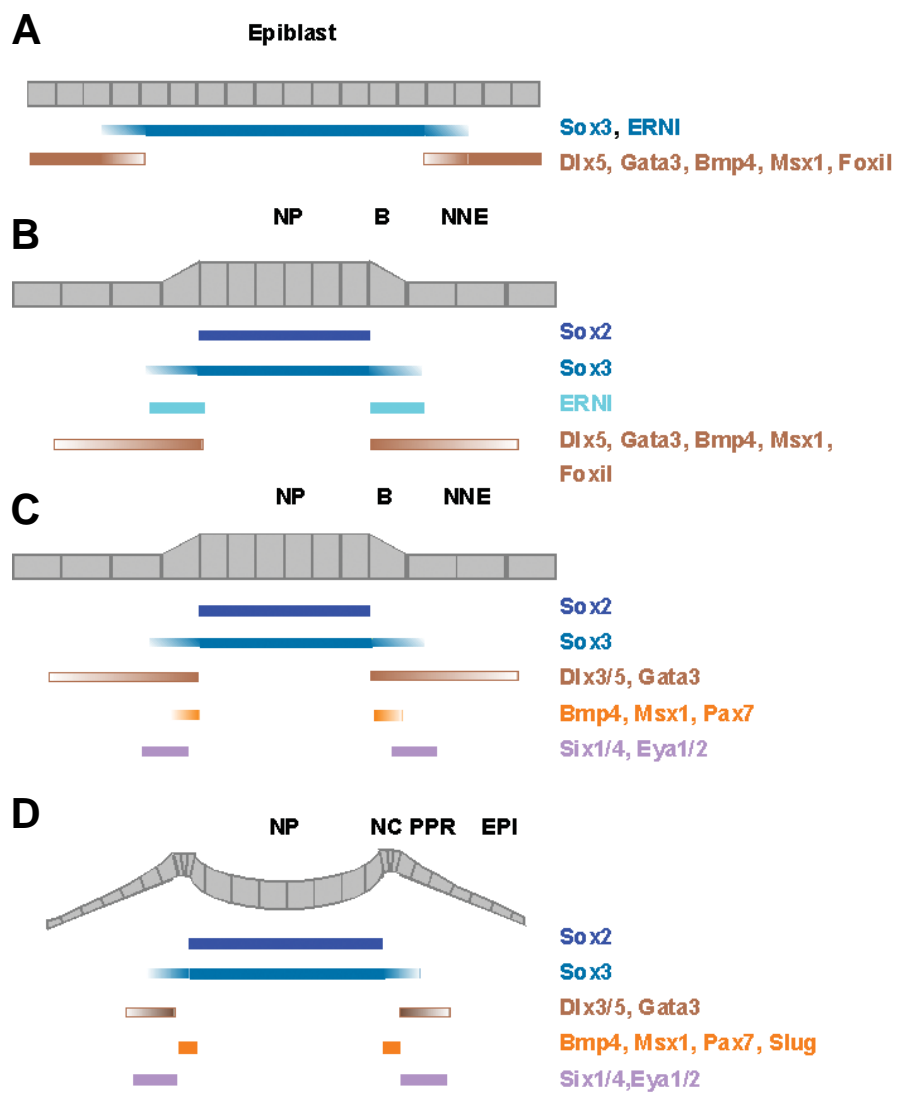

Fig. 2. Changes in gene expression from gastrula to early somite stages. Diagrams show a cross section through chick embryos at gastrula (A), head process (B), 1-2-somite (C) and 4-5-somite (D) stages. (A) At gastrula stages, the epiblast is roughly subdivided into neural and non-neural territories. (B) The neural plate can be identified morphologically expressing definitive neural markers (Sox2), while preneural markers (ERNI) become confined to the border, where non-neural markers become upregulated (D/x5, Gata3, BMP4, Msx1, Foxil). (C) Preplacodal markers begin to be expressed (Six1, Six4, Eya2); there is some overlap between BMP4, Msx1 and Pax7, which are later confined to the neural folds where neural crest cells arise. (D) Neural folds are morphologically distinct and express neural crest cells markers (Slug, Pax7). There is no overlap between neural crest and preplacodal genes. $N P$, neural plate; $B$, border; NNE, non-neural ectoderm; NC, neural crest; PPR, preplacodal region; EPI, future epidermis. 
leads to an enlarged otic vesicle only within the normal ear field, where both genes are co-expressed. In contrast, loss of both genes completely abolishes the formation of otic structures (Solomon, et al., 2004; Hans, et al., 2007). Experiments in Xenopus demonstrate an even earlier role for Foxil; loss of Foxila function leads to an expansion of the neural plate at gastrula stages, while its overexpression suppresses neural development while simultaneously promoting epidermal character (MatsuoTakasaki, et al., 2005). It should be noted that so far an early role for Foxi class genes has not been demonstrated in mouse; this may be due the difference in Foxi gene expression in different species. Together, these findings identify Foxil as one of the early players in ectodermal patterning involved in setting the border between neural and non-neural ectoderm and as a prerequisite for otic and epibranchial development. Future experiments will need to address its potential role in the formation of other placodes and its epistatic relation to genes specific for the placode territory.

Thus, members of the DIx, Msx and Foxi family are expressed early and in a broad domain and regulate neural crest and placode specific genes. They are therefore at the top of a hierarchy controlling the specification of cells that arise from the border region and are likely to be intracellular mediators of the signalling pathways that pattern the ectoderm and position the placode territory next to the cranial neural plate.

\section{The Six/Eya/Dach network in placode development}

Among the many transcription factors expressed in the preplacodal region, only members of the Six and Eya families match precisely the location of all placode precursors and are subsequently maintained in all placodes, but lost from nonplacodal ectoderm. They have been implicated in multiple processes during placode formation and are therefore likely candidates to be involved in defining the placode territory at early developmental stages.

\section{Six and Eya genes in sensory organ formation}

Their importance in sensory organ development was initially reported in Drosophila, where their homologues sine oculis (so) and eyes absent (eya) form a non-linear, regulatory network that together with dachshund (dac) control eye development and photoreceptor cell specification (for review: Kumar and Moses, 2001; Donner and Maas, 2004; Pappu and Mardon, 2004; Rebay, et al., 2005). Loss of any of these genes results in defects or absence of the eye (Bonini, et al., 1993; Cheyette, et al., 1994; Mardon, et al., 1994; Quiring, et al., 1994; Serikaku and O'Tousa, 1994), while their overexpression leads to ectopic eye formation in restricted positions of other imaginal discs (Halder, et al., 1995; Bonini, et al., 1997; Chen, et al., 1997; Pignoni, et al., 1997; Shen and Mardon, 1997; Weasner, et al., 2007). So, eya and dac regulate each others' expression and function downstream of the Pax6 homologue eyeless (ey): their expression and eye-inducing ability depends on the presence of functional Ey (Halder, et al., 1998; Niimi, et al., 1999; Bui, et al., 2000; Punzo, et al., 2002; Pappu, et al., 2005; for review: Kumar and Moses, 2001; Pappu and Mardon, 2004).

In vertebrates, six Six genes have been identified (Six1-6), while there are only four Eya genes (Eya1-4) (for review: Kawakami, et al., 2000; Wawersik and Maas, 2000; Hanson, 2001; Rebay, et al., 2005). Of those Six1, Six4, Eya1 and Eya2 are found in the pre-placodal region, while combinations of different family members are coexpressed in mature placodes (Mishima and Tomarev, 1998; Esteve and Bovolenta, 1999; Sahly, etal., 1999; Kobayashi, et al., 2000; Pandur and Moody, 2000; McLarren, et al., 2003; Bessarab, etal., 2004; Schlosser and Ahrens, 2004; Litsiou, etal., 2005). Of the Eya gene family, only Eya3 is never found in any placode. As in the fly, they are often colocalised with members of the Pax gene family (e.g. Pax6: lens, olfactory; Pax2: otic and epibranchial; Pax3: trigeminal) although their regulatory relationship appears to be more complicated. For example, in the mouse olfactory ectoderm initial expression of Six3, Eya1 and Dach1 proteins is Pax6 independent, while their maintenance in the placode requires Pax6 (Purcell, et al., 2005). Likewise, in the presumptive lens ectoderm, Pax 6 is controlled by Six 3 but once the placode is formed Six 3 expression depends on Pax6 activity (Purcell, et al., 2005; Liu, et al., 2006). In the ear Pax2, Eya1 and Six 1 are expressed in partially overlapping domains; Eya 1 and Six 1 expression is independent of Pax2, while Six 1 depends on Eya1 function (Zheng, et al., 2003; Burton, et al., 2004). In the preplacodal region Sixand Eyatranscripts are present prior to the onset of Paxgene and are therefore likely to act independently.

The importance of Six and Eya genes for normal placode development has been demonstrated through loss-of-function in mouse, zebrafish and humans. Eya1 and Six1 have been studied extensively and play a role in the formation of most placode derivatives (see below), reflecting their widespread expression in the preplacodal region. Likewise, mutations in Eya4 and Six5 are associated with defects in placode derivatives (Klesert, et al., 2000; Wayne, et al., 2001; Zhang, et al., 2004), while information about Six2 and Eya2 is very sparse. Mice lacking Eya2 function have been generated, however, their placodal phenotype has not been described in detail (Grifone, et al., 2007). So far, no placode phenotype has been described for Six4 mutant mice (Ozaki, et al., 2001; Grifone, et al., 2005); one possible explanation may be functional redundancy between genes of the same family that are normally co-expressed. In support of this, Six1 and -4 double knock-out mice show a more severe muscle, kidney and trigeminal ganglion phenotype than Six1 mutants alone (Grifone, et al., 2005; Konishi, et al., 2006; Kobayashi, et al., 2007). However, it is not know whether this is also the case for other placodes.

Mice heterozygous for Eya1 display a phenotype very similar to an inherited form of deafness in humans, the Branchio-OtoRenal (BOR) syndrome, a form of conductive hearing loss due to defects in middle ear development (Abdelhak, et al., 1997; Xu, et al., 1999). Mice completely lacking Eya1 function have severe inner ear defects (Johnson, et al., 1999; Xu, et al., 1999; Li, et al., 2003; Zou, et al., 2004; Friedman, et al., 2005; Zou, et al., 2006): otic development arrests at vesicle stages, sensory patches remain small and while cochlear-vestibular neurons initially form, they later undergo apoptosis. In addition, the trigeminal ganglion is reduced in size, epibranchial placode derived petrosal, geniculate and nodose ganglia are missing or greatly reduced and fail to express neuronal determination genes. Zebrafish dogeared mutants (Eya1) also show ear defects and the development of the lateral line placodes is impaired, however cranial ganglia are generally unaffected (Kozlowski, et al., 2005; Whitfield, 2005). Eya1 mutations in humans are also associated with congenital 
eye defects (Azuma, et al., 2000), although these have not been described in mice. Finally, mutations in the eya-homologous region of Eya4 lead to late-onset deafness in humans (Wayne, et al., 2001; Zhang, et al., 2004; Schonberger, et al., 2005).

Like Eya1, Six1 has been implicated in normal development of the inner ear and mutations in human Six 1 cause BOR syndrome like Eya1 mutations (Ruf, et al., 2004). Mice lacking Six1 function display very similar phenotypes to Eya1 mutant mice: otic vesicles are small, lack the cochlea and semicircular canals and do not form a cochlear-vestibular ganglion (Laclef, et al., 2003; Li, et al., 2003; Zheng, et al., 2003; Ozaki, et al., 2004). In addition, trigeminal and epibranchial placode derived neurons are reduced or absent and development of the olfactory epithelium is impaired. In zebrafish, Six1 promotes the formation of hair cells by increasing their proliferation, while inhibiting neurogenesis by inducing apoptosis (Bricaud and Collazo, 2006). Finally, Six 5 mutations lead to cataract formation in the lens (Klesert, et al., 2000; Sarkar, et al., 2000; Bateman, et al., 2006) and are associated with BOR syndrome in humans (Hoskins, et al., 2007).

The widespread defects in almost all placode derivatives in Six1 and/or Eya1 mutants argues for a conserved function of this network during sensory placode formation or for an involvement at very early stages development, maybe in the preplacodal region. Unfortunately, none of the above studies has addressed this issue. In Xenopus, Six1 function has been assessed at preplacodal stages (Brugmann, et al., 2004), where it promotes the expression of other preplacodal genes like Eya1, while repressing neural, neural crest and epidermal fates. These findings point to a potentially early role of Six and Eya proteins in ectodermal patterning by establishing the preplacodal region and conferring common preplacodal properties (see below). However, further studies are required to determine their precise role at these early stages.

\section{Molecular function and targets of the Six/Eya/Dach network}

Six, Eya and Dach proteins are thought to interact physically and to act as a transcription factor complex to activate downstream target genes (for review: Relaix and Buckingham, 1999; Kawakami, et al., 2000; Wawersik and Maas, 2000; Hanson, 2001; Silver and Rebay, 2005). Six genes encode homeodomain DNA binding proteins (Seo, et al., 1999; Kawakami, et al., 2000) that can act either as transcriptional activators or repressors depending on the recruitment of appropriate cofactors. One group of such cofactors are the Dach proteins (Mardon, et al., 1994; Hammond, etal., 1998; Davis, et al., 1999), nuclear factors which together with other repressors inhibit target gene transcription. In addition, Dach proteins themselves seem to bind DNA (Ikeda, et al., 2002) and modulate BMP signalling by interacting with Smad4 (Wu, et al., 2003; Kida, et al., 2004). Eya proteins represent transcriptional coactivators that are recruited to DNA via their interaction with Six proteins (Ohto, et al., 1999; Silver, et al., 2003). Recently, Eya proteins have been shown to have catalytic activity as protein phosphatases and this activity appears to be required for their function as activators ( $\mathrm{Li}$, et al., 2003; Rayapureddi, et al., 2003; Tootle, et al., 2003). Direct binding has indeed been shown for Eya and Dach and Six and Eya proteins (Chen, et al., 1997; Pignoni, et al., 1997; Ohto, et al., 1999; Ikeda, et al., 2002; Li, et al., 2003; Silver, et al., 2003) and nuclear translocation of Eya protein is dependent on its interaction with members of the Six family (Ohto, et al., 1999). Furthermore, Groucho repressors have been shown to bind Six proteins, in particular Six3 directly and thus modulate its activity (Kobayashi, et al., 2001; Zhu, et al., 2002).

So far only a few direct target genes have been identified, among them cMyc and CyclinA1 and-D1, all involved in cell cycle control (Coletta, et al., 2004; Yu, et al., 2006). Indeed, both Six1 and Eya2 appear to promote tumorigenesis by enhancing proliferation (Coletta, et al., 2004; Zhang, et al., 2005; Yu, et al., 2006), while high levels of Eya2 seem to trigger apoptosis (Clark, et al., 2002). In the otic vesicle, loss of Eya1 and Six1 leads to reduced proliferation, while in Drosophila loss of either so, dac or eya initially results in overgrowth followed by cell death (Bonini, et al., 1993; Pignoni, et al., 1997; Xu, etal., 1999; Li, et al., 2003; Ozaki, etal., 2004; Kozlowski, etal., 2005; Zou, etal., 2006). In zebrafish, Six1 plays opposite roles in hair cells and otic neurons that arise from common sensory patches. Six1 induces apoptosis in neuronal precursors, but promotes proliferation in sensory hair cells (Bricaud and Collazo, 2006) thereby regulating the balance between both cell types. Thus, the Six/Eya/Dach network may control the number of placode precursors during early stages of development, differential proliferation and apoptosis during morphogenesis and the number of precursors for different cell types within placodes.

Although data in Drosphila show that the Six/Eya/Dach cassette can induce cell fate changes by making non-eye cells adopt an eye fate, the exact molecular mechanisms of how they operate during this process are still unknown (Bonini, et al., 1997; Pignoni, et al., 1997; Shen and Mardon, 1997; Weasner, et al., 2007). Eyeless is directly regulated by sine oculis, however further targets have not been identified. In vertebrates, functional Six and Eya are required for myogenesis (Heanue, et al., 1999) for review Relaix and Buckingham, 1999), but the evidence that they control cell specification without affecting proliferation during placode development is very poor. As mentioned above, misexpression of Six1 promotes preplacodal gene expression (Brugmann, et al., 2004), but by itself or in combination with Eya is insufficient to generate mature placodes or to activate Pax genes (Christophorou and Streit, unpublihsed). Since only cells within the preplacodal region are competent to respond to placode inducing signals, one potential role of Six and Eya genes may be to impart competence to such inducing factors.

In summary, there is considerable evidence for a crucial role of the Six/Eya/Dach network in various aspects of placode development, however in many cases the precise molecular mechanisms remain to be identified. Characterisation of direct targets in different cellular contexts will be an important step to understand their function.

\section{Signalling pathways inducing the neural plate border and the preplacodal region}

Formation of the preplacodal region is initiated through a series of events that first define the border of the neural plate and subsequently subdivide the border into placode and neural crest precursors. This is achieved through interactions with surrounding tissues - neural plate, future epidermis and the underlying head mesoderm - which secrete factors that promote or attenuate placode formation. Thus, different signalling pathways converge 
to position the placode territory in the head ectoderm next to the neural plate.

\section{FGF pathway}

Several observations implicate FGFs as one of the factors that initiate the formation of the border region. In the chick, misexpression of FGF8 rapidly induces ectopic expression of a set of genes normally coexpressed in the border: ERNI, Sox3, DIX5 and MsX1 (Streit and Stern, 1999; Streit, et al., 2000; Litsiou, et al., 2005). However, FGF alone is not sufficient to generate any of the cell types that arise from the border: neural crest and placodes (Mayor, et al., 1997; LaBonne and BronnerFraser, 1998; Monsoro-Burq, et al., 2003; Ahrens and Schlosser, 2005; Litsiou, et al., 2005). In contrast, FGF inhibition using the antagonist SU5402 or dominant negative receptors shows that active signalling through the FGF pathway is required for at least some of the border genes (Sox3, ERN/;Streit, et al., 2000) and for the generation of border derivatives (Mayor, et al., 1997; LaBonne and Bronner-Fraser, 1998; Monsoro-Burq, et al., 2003; Ahrens and Schlosser, 2005; Litsiou, et al., 2005). Together, these findings argue for a role of FGFs in promoting border character in ectodermal cells as a prerequisite to generate neural crest and placode cells. Accordingly, FGFs are expressed in the head mesoderm and trunk paraxial mesoderm that comes to underlie the border region and in Xenopus at the edge of the neural plate (Niswander and Martin, 1992; Shamim and Mason, 1999; Streit and Stern, 1999; Ahrens and Schlosser, 2005).

In addition, FGFs seem to play a role in preplacodal induction at slightly later stages. FGF signalling from surrounding tissues (head mesoderm in chick, neural plate in Xenopus) is required for the induction of preplacodal markers, while ectopic expression of FGF8 promotes expression of Eya2, but not of any other placode specific gene (Brugmann, et al., 2004; Ahrens and Schlosser, 2005; Litsiou, et al., 2005). Thus, FGFs play a dual role in the supporting placode formation: initially they promote the expression of border genes and later initiate expression of a subset of preplacodal markers.

\section{BMP pathway}

Modulation of BMP signalling has been widely implicated in early ectodermal patterning (Wilson, et al., 1997; Marchant, et al., 1998; Barth, et al., 1999; Tribulo, et al., 2003; for review Sasai and De Robertis, 1997; Aybar and Mayor, 2002; Stern, 2005). Indeed, Foxil is dependent on BMP signalling in fish and frogs (Matsuo-Takasaki, et al., 2005; Phillips, et al., 2006). In zebrafish, Foxil expression is reduced or lost in BMP7 and BMP2a mutants, while it is downregulated in Xenopus in the presence of the BMP antagonist Chordin. In contrast, overexpression of BMP4 causes an expansion of Foxil at the expense of neural tissue. Likewise, BMP signalling is required for DIx gene expression in chick, frog and fish (Nguyen, et al., 1998; Feledy, et al., 1999; Pera, et al., 1999; Luo, et al., 2001), while Ms $\times 1$ is a direct target of BMP signalling and mediates its ability to promote epidermis (Suzuki, et al., 1997). These findings implicate BMP activity, like FGF signalling, in the regulation of border specific genes.

One model mainly based on experiments in Xenopus suggests that a gradient of BMP activity within the ectoderm acts to
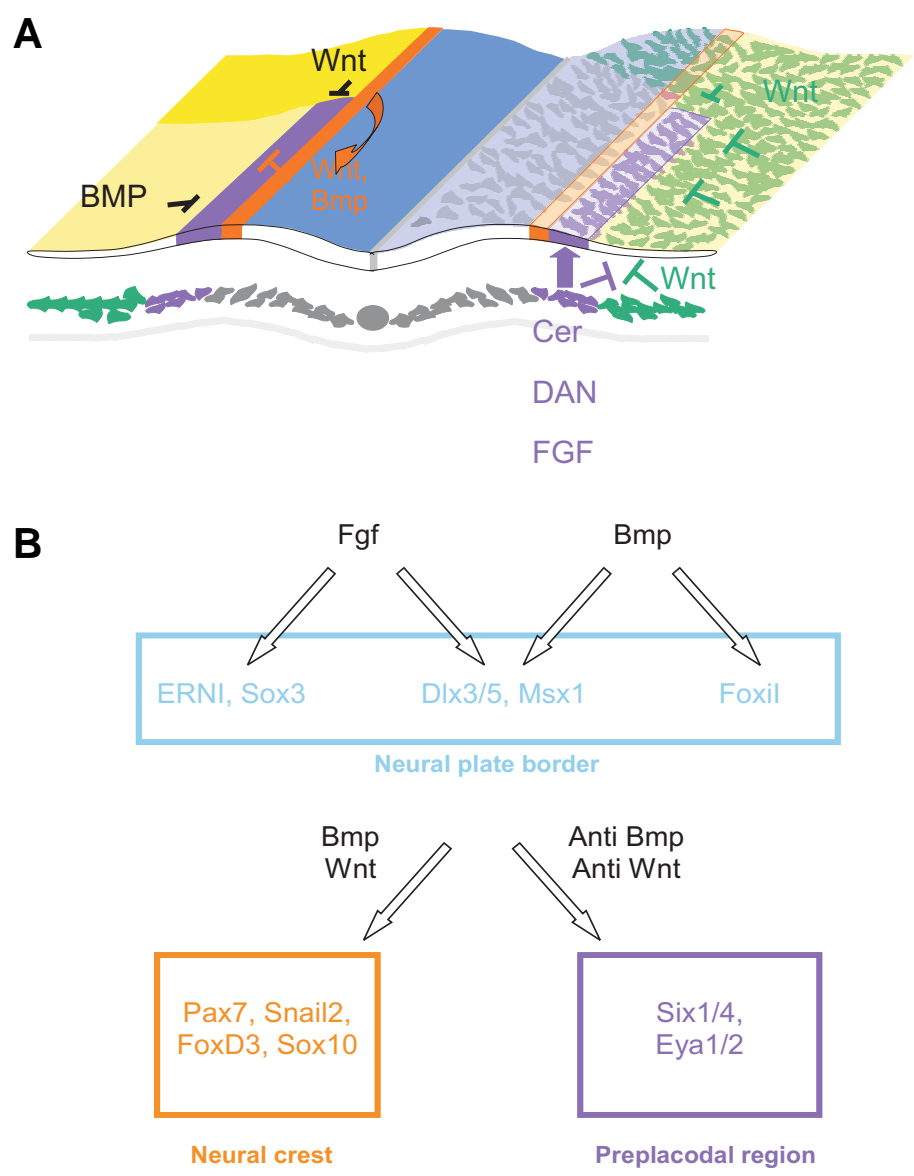

Fig. 3. Model for induction of the preplacodal region. (A) The diagram shows a cross section through a chick embryo at the 2-4 somite stage viewed from anterior towards posterior (modified from Litsiou, et al., 2005). Ectodermal signals that influence the position of the preplacodal region are schematised on the left, whereas mesoderm derived signals are shown on the right. The preplacodal region (purple) is surrounded by inhibitory signals from the lateral (light yellow; BMP) and posterior (yellow; Wnt) ectoderm, from the neural folds (orange; Wnt, BMP) and from the lateral and posterior mesoderm (green; Wnt). FGF, Wnt antagonists and BMP antagonists (purple) from the mesoderm underlying the preplacodal region protect the overlying ectoderm from these inhibitory signals and allow the formation of placode precursors. (B) Signals and transcription factors in the border and preplacodal region. FGFs and BMPs act upstream of border specific transcription factors. Once the border is established, levels of BMP and Wnt signalling determine whether border cells generate neural crest or placode cells.

allocate different cell fates for review (Sasai and De Robertis, 1997; Aybar and Mayor, 2002; Vonica and Brivanlou, 2006). In support of this idea, Xenopusanimal caps treated with different concentrations of BMP antagonists form epidermis in the presence of high levels of BMP activity, while neural crest and preplacodal cells are generated at intermediate and neural plate at low levels (Wilson, et al., 1997; Tribulo, et al., 2003; Brugmann, etal., 2004; Glavic, etal., 2004). Likewise, zebrafish mutants with reduced BMP activity (and thus a shallower gradient) show a relatively larger expansion of the neural crest territory than of the neural plate (Nguyen, et al., 1998; Barth, et al., 1999). However, the placode territory is merely displaced, 
but not expanded and different placodes are affected differentially arguing against a simple gradient model (Neave, et al., 1997; Nguyen, et al., 1998).

In chick, the main region sensitive to modulation of BMP signalling is the neural plate border itself (Streit and Stern, 1999). Here, misexpression of BMP antagonists leads to a shift of the border towards the non-neural ectoderm, while misexpression of BMP4 narrows the neural plate and shifts the border medially. In contrast, modulation of the BMP pathway away from the border does not have any effect. Likewise, local reduction of BMP signalling close to the preplacodal region expands this territory in chick and Xenopus, but is not sufficient to induce it ectopically in future epidermis (Glavic, et al., 2004; Ahrens and Schlosser, 2005; Litsiou, et al., 2005). One possible explanation to reconcile these differences is that Xenopus animal caps may contain border territory and are therefore particularly sensitive to changes in BMP activity.

Thus, modulation of BMP activity and loss- or gain-of-function experiments for border specific transcription factors show the same effect: they shift the border of the neural plate. It is therefore likely that BMP signalling acts via mediators such as Foxil, Dlx and Msx to alter preplacodal gene expression indirectly.

\section{Wnt pathway}

As discussed above, both FGF and BMP pathways modulate the expression of preplacodal genes: FGF8 activates Eya2, while inhibition of BMP signalling expands preplacodal markers (Brugmann, et al., 2004; Ahrens and Schlosser, 2005; Litsiou, et al., 2005). However, even the combination of FGF and BMP antagonists is not sufficient to induce preplacodal character in ectoderm away form the endogenous placode territory or in the future trunk ectoderm (Brugmann, et al., 2004; Ahrens and Schlosser, 2005; Litsiou, et al., 2005). Like inhibition of BMP, misexpression of Wnt antagonists leads to an expansion of preplacodal gene expression at the expense of future epidermis (Brugmann, et al., 2004; Litsiou, et al., 2005). Interestingly, Six 1, -4 and Eya2 also extend into the trunk ectoderm, where placode formation is not normally observed. In contrast, activation of canonical Wnt signalling represses preplacodal gene expression suggesting that Wnt attenuation allows the specification of placode precursors (Litsiou, et al., 2005). Furthermore, a combination of FGF with Wnt and BMP antagonists induces an ectopic preplacodal region in naïve ectoderm in the absence of neural and mesodermal tissue indicating that these factors promote placode character directly (Litsiou, et al., 2005). Thus, temporal and spatial integration of all three signals is important to generate placode precursors.

Unlike placode precursors, neural crest cells require canonical Wnt signalling (for review: Aybar and Mayor, 2002; Knecht and Bronner-Fraser, 2002). These findings suggest that at the border of the neural plate exposure to different levels of Wnt activity determines whether cells adopt placode or neural crest cell fates. Indeed, activation of Wnt signalling expands neural crest markers into the placode territory, while its inhibition has the opposite effect (Litsiou, et al., 2005). In this context it is interesting that at slightly later stages when the otic placode begins to form, Wnt signalling promotes placode formation: $\mathrm{Pax}^{+}$cells that activate the pathway become otic, while those that do not, develop into epidermis (Ohyama, et al., 2006). These findings highlight that interpretation of the same signalling pathway is highly context dependent and is determined by the developmental history of individual cells.

\section{A model for induction of the preplacodal region}

The data summarised above highlight that induction of the preplacodal region is a multi-step process, which requires the integration of different signals produced by different tissues. The following model tries to integrate tissue interactions and signalling pathways (Fig. 3). As a first step, a border territory is set up in the early neurula ectoderm between future neural and epidermal cells. Genes specific for this region are under the control of FGF and/or BMP signalling. BMP4 and -7 are expressed in the nonneural ectoderm and transcript levels and phospho-smad activity are highest at the edge of the neural plate (Fainsod, et al., 1994; Streit, et al., 1998; Streit and Stern, 1999; Faure, et al., 2002), which in turn may lead to the upregulation of some border genes (DIx, Msx, Foxil). FGFs emanating from the organiser and the mesoderm underlying the border maintain the expression of Sox3 and ERNI and cooperate with BMPs to promote D/xand Msxgene expression. Once established the border gives rise to two different cell types: neural crest and placodes. BMP4and - 7 transcripts concentrate in the forming neural folds (Fainsod, et al., 1994; Liem, et al., 1995), where Wnts begin to be expressed; together they promote formation of neural crest cells. The future heart mesoderm expands anteriorly and comes to underlie the placode territory (Kimmel and Warga, 1988; Keller and Tibbetts, 1989; Tam, et al., 1997; Redkar, et al., 2001; Hochgreb, et al., 2003). This tissue expresses FGF4, the BMP antagonist DAN and the Wnt inhibitor Cerberus (Ogita, et al., 2001), while more lateral and posterior mesoderm contains high levels of Wnt8c (Hume and Dodd, 1993; Litsiou, et al., 2005). Wnt6 is found in the trunk, but not the head ectoderm (Garcia-Castro, et al., 2002; Schubert, et al., 2002). Thus, the preplacodal region is surrounded by inhibitory factors at its medial, lateral and posterior edges. Signals from the heart mesoderm protect the overlying ectoderm from these inhibitory influences and allow it to adopt placode fate.

\section{Anterior-posterior patterning of the preplacodal region}

Within the preplacodal region precursors for different placodes are intermingled, although some separation of individual populations along the anterior posterior axis is already apparent. Precursors for anterior placodes (adenohypophysis, olfactory, lens) are located in the rostral preplacodal region, while precursors for posterior placodes (trigeminal, epibranchial, otic, lateral line) are restricted more caudally (D'Amico-Martel and Noden, 1983; Couly and Le Douarin, 1985; Couly and Le Douarin, 1988; Kozlowski, et al., 1997; Streit, 2002; Bhattacharyya, et al., 2004; Litsiou, et al., 2005). This approximate subdivision is reflected by the onset of regionally restricted expression of transcription factors (and few other genes), shortly after the induction of the placode territory. As development proceeds, the preplacodal region becomes molecularly divided in successively smaller sub-domains such that by the time placodes can be identified morphologically each appears to have a unique transcription factor code (Torres and Giraldez, 1998; Bailey and Streit, 2006; Schlosser, 2006). These changes 
Early neurula

\begin{tabular}{|r|}
\hline \multicolumn{3}{|c|}{ Six1/4, Eya1/2 } \\
\begin{tabular}{|r|r|}
\hline Pax6, Six3 & Irx1/2/3 \\
\hline Otx2 & Gbx2 \\
\hline
\end{tabular}
\end{tabular}

Early somite

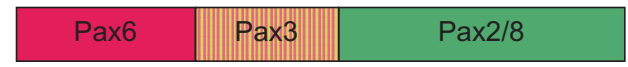

Fig. 4. Anterior-posterior patterning of the preplacodal region. At early neurula stages preplacodal markers are expressed along the entire length of the preplacodal region (anterior to the left, posterior to the right). Soon thereafter, regionalised gene expression is apparent: Pax6, Six3 and Otx 2 are concentrated anteriorly, while Irx 1-3 and Gbx2 are restricted posteriorly. At early somite stages Pax 3 is upregualted in the ophthalmic part of the trigeminal region and Pax2 and -8 in the otic/epibranchial territory. Note: the relative boundaries of gene expression are inferred from data in the literature that show in situ hybridisation with a single gene (references see text). Double in situ hybridisation is required to confirm this model.

in gene expression have recently been reviewed in detail in Xenopus (Schlosser, 2006) and therefore only some of the early aspects of patterning will be highlighted below.

\section{Transcription factors in anterior-posterior patterning}

At neurula stages, the rostral preplacodal region begins to express Otx2, Six3, Pitx3, Dmbx1 and Pax6, while its caudal part is characterised by Irx1, -2 and-3 and Gbx2(Li, et al., 1994; BallyCuif, etal., 1995; Oliver, etal., 1995; Pannese, etal., 1995; Hirsch and Harris, 1997; Bellefroid, et al., 1998; Gomez-Skarmeta, etal., 1998; Shamim and Mason, 1998; Goriely, et al., 1999; Zhou, et al., 2000; Glavic, et al., 2002; Gogoi, et al., 2002; Matsumoto, et al., 2004; Dutta, et al., 2005; Zilinski, et al., 2005; Liu, et al., 2006; for review: Schlosser, 2006). Although these patterns appear to be roughly complementary, closer inspection reveals that different transcripts do not share the same rostro-caudal boundary (Fig. 4). Rather pairs of transcription factors have boundaries at different levels: Six 3 expression abuts $I r x$, while Otx2 and Gbx2 abut at slightly more posterior levels. These patterns are very reminiscent of their expression in the neural plate, where the same pairs of genes control the subdivision of the brain into different compartments (for review: Martinez, 2001; Nakamura, 2001; Hidalgo-Sanchez, etal., 2005). Gbx2 and Otx2 are involved in positioning the midbrain-hindbrain boundary (Broccoli, et al., 1999; Millet, et al., 1999; Katahira, et al., 2000; Acampora, et al., 2001; Li and Joyner, 2001), while Six3 and Irx3 define a boundary in the forebrain that later corresponds to the zona limitans intrathalamica (Kobayashi, et al., 2002).

At early somite stages, members of the Pax gene family become expressed in more restricted domains within the preplacodal region (Bang, et al., 1997; Hirsch and Harris, $1997 \mathrm{Li}$, 1994 \#195; Stark, et al., 1997; Heller and Brandli, 1999; Groves and Bronner-Fraser, 2000). Pax3 is detected in the ophthalmic part of the trigeminal, Pax8in the otic and Pax2epibranchial, otic and lateral line territory. Together Pax genes cover the entire placode region in non-overlapping patterns except Pax 2 and -8 which are co-expressed in the future otic placode. Interestingly, in the neural plate Pax2 and -6represent another pair of transcription factors that position a boundary, in this case between future diencephalon and mesencephalon (Okafuji, etal., 1999; Schwarz, et al., 1999; Matsunaga, et al., 2000; Schwarz, et al., 2000). As it is the case for Six3/Irx3 and Otx2/Gbx2, in the brain Pax2 and 6 negatively cross regulate each other, leading to sharpening of the molecular boundary and separation of different cell fates. It is tempting to speculate that the same molecular mechanisms that pattern the brain also operate to impart regional identity to the placodes.

Loss of Otx2 function results in severe defects in the head including the brain, olfactory and lens placode as well as pattering of the otic vesicle (Acampora, et al., 1995; for review: Acampora, et al., 2001). However, because of the severe fore- and midbrain defects, it has been difficult to asses its direct function in placode development without the availability of tissue specific knock outs. Mice deficient in Gbx2 (Lin, et al., 2005) and Pax2 function show patterning defects in the otic vesicle (Torres, et al., 1996; Burton, et al., 2004), while loss of Six3 or Pax6 affects lens and olfactory development (Hogan, et al., 1988; Quinn, et al., 1996; Grindley, et al., 1997; Lagutin, et al., 2003; Liu, et al., 2006). In Xenopus, Irx1 is required for the expression of the early preplacodal marker Six 1 and later placode specific genes like Sox2and Pax2(Glavic, et al., 2004). Thus, mutation in or loss of any of these genes leads to defects in placode development, although their role in early patterning of the preplacodal region remains elusive probably due to functional redundancy with other members of the same family that are expressed in similar patterns (Schlosser, 2006).

\section{Signalling pathways in anterior-posterior patterning}

In the neural plate, regional identity is initially set up through the graded activity of Wnts, FGF and retinoic acid, all of which possess posteriorising activity and control some of the transcription factors described above (for review: Yamaguchi, 2001; Wilson and Houart, 2004; Kiecker and Lumsden, 2005; Rhinn, et al., 2006). Do the same signalling pathways control anterior posterior patterning in the preplacodal region? Experiments in Xenopus revealed that the formation of neural crest cells indeed requires Wnt and retinoic acid activity and that anterior neural folds, which normally do not generate neural crest cells, do so in the presence of these factors (Villanueva, et al., 2002). In chick and Xenopus, the expression of preplacodal markers can be expanded into the trunk ectoderm in the presence of Wnt antagonists (Brugmann, et al., 2004; Litsiou, et al., 2005). In contrast, the zebrafish mutants masterblind and headless, in which Wnt signalling is overactivated, show a loss of anterior placodes (lens, olfactory), but an expansion of trigeminal neurons around the anterior neural plate (Kim, et al., 2000; Heisenberg, etal., 2001). Thus, differential activation of the Wnt pathway along the rostro-caudal axis influences patterning of the preplacodal region suggesting that the mechanisms that allocate regional identity in the neural plate may act more globally to pattern the entire ectoderm.

\section{Cells in the preplacodal region share a common devel- opmental programme}

As outlined at the beginning of this review, placodes form diverse structures with different functional properties and a vari- 
ety of different cell types. Yet, they have variously been grouped together as a family and considered as related structures. Does this grouping reflect a meaningful developmental concept and does the preplacodal region represent a 'basic placode state'? At least two conditions need to be fulfilled. First, at some point along their developmental history placode cells should acquire a unique state that distinguishes them from other ectodermal derivatives. This is clearly the case (see above): placode precursors occupy a unique region in the embryonic ectoderm surrounding the cranial neural plate and they express a unique set of molecular markers. Furthermore, the preplacodal region is induced by a specific combination of tissues and signals that is different from the signals that induce neural, neural crest and epidermal precursors. Second and more importantly, the 'preplacode state' should be a unique property of placode precursors and be a prerequisite for cells to become mature placodes.

Recent experiments on otic induction in the chick embryo provide strong evidence that indeed ectodermal cells have to acquire preplacode character before they are responsive to the otic inducer FGF (Martin and Groves, 2006). Only cells within the preplacodal territory are responsive to FGF, while future epidermal cells are not. Anterior epiblast from chick gastrula stage embryos normally never gives rise to the otic placode, but is competent to do so when transplanted into the ectoderm next to the hindbrain, where the otic placode normally forms. Likewise, explants of anterior epiblast do not express otic markers when cultured in isolation or when treated with FGF. However, when the same tissue is first transplanted into the preplacodal region for a brief period (ca. $8 \mathrm{hrs}$ ), it initiates gene expression characteristic for this territory (Eya2, D/x) and when explanted can now respond to FGF by expressing otic markers. These experiments support the idea that the preplacodal region has unique properties and suggest that the acquisition of preplacodal character is an essential step in otic induction and a prerequisite for cells to form mature placodes.

But do all placode precursors share a common developmental history? Recent evidence indicates that at the very least they initially share common characteristics: unlike any other part of the ectoderm, the entire preplacodal region is specified as lens (Bailey, et al., 2006). When the preplacodal region is subdivided into four portions along the anterior posterior axis and cultured in neutral environment, no markers specific for olfactory, trigeminal or otic placodes are expressed - the tissue is not specified. However, in the same experiment, explants from all parts of the preplacodal region, even cells that normally never contribute to the lens, but to the otic placode, form lens-like structures. These explants follow the same sequence and timing of gene expression as observed during normal lens development: they initially express Pax6, followed by L-maf and Foxc1 and finally, $\delta$ - and $\alpha$ crystallin. Thus, all placode cells regardless of their ultimate fate initially possess lens character suggesting that in normal development placode induction is intimately linked with lens suppression. The lens probably represents the simplest placode derivative: it only generates two cell types, lens fibre and lens epithelial cells. The only other non-neurogenic placode, the anterior pituitary, which develops in the anterior midline, is easily transformed into lens in the absence of sonic hedgehog from underlying axial structures (Sbrogna, et al., 2003; Dutta, etal., 2005; Zilinski, etal., 2005). In contrast to the lens and anterior pituitary, all other placodes give rise to sensory neurons and/or sensory cells. Thus, lens suppression must be accompanied by the acquisition of neurogenic properties in non-lens placodes. Together, these results provide good support for the concept of a common ground state for all sensory placodes and for the importance of the preplacodal region in the developmental history of placode cells.

What are the lens repressing signals? FGFs appear to be the main players to initiate lens repression: activation of the FGF pathway inhibits the expression of the presumptive lens marker Pax6(Bailey, etal., 2006). FGFs (FGF3, FGF10, FGF19 depending on species) also play an important role in otic induction (Ladher, et al., 2000; Vendrell, et al., 2000; Leger and Brand, 2002; Maroon, et al., 2002; Wright and Mansour, 2003) and lens specification is abolished in preplacodal explants in the presence of FGF2, while the otic marker Pax2 is induced (Bailey and Streit, unpublished). In contrast, exposure to FGF8 is sufficient to induce olfactory character from lens specified ectoderm (Bailey, et al., 2006). Finally, FGF signalling (FGF3, -8) has been implicated in epibranchial placode specification and in the generation of the adenohypophysis, a placode forming in the anterior midline (Herzog, et al., 2004; Nechiporuk, et al., 2007; Nikaido, et al., 2007; Sun, et al., 2007). Thus, FGFs play a key role in restricting lens fate and in simultaneously inducing other placodes. The next important question to address is how the activation of the same signalling pathway in the preplacodal region elicits different responses leading to the formation of placodes with different identities.

\section{Future perspectives}

In summary, prior to the appearance of morphological placodes induction of the preplacodal region is an essential process, which imparts unique identity to all placode precursors. The signalling pathways involved are similar to those implicated in neural and neural crest induction, however, timing and levels differ. Recent evidence argues that all placodes initially share a common ground state as lens and thus possess a common developmental history, before they diversify later. Surprisingly, FGF signalling appears to play a role during the induction of different placodes from this ground state. The future challenge is to unravel how different pathways cooperate with FGF signalling to impart placode identity and to establish networks of transcription factors that control this process.

\section{References}

ABDELHAK, S., KALATZIS, V., HEILIG, R., COMPAIN, S., SAMSON, D., VINCENT, C., WEIL, D., CRUAUD, C., SAHLY, I., LEIBOVICI, M. et al. (1997). A human homologue of the Drosophila eyes absent gene underlies branchio- oto-renal (BOR) syndrome and identifies a novel gene family. Nat Genet, 15: 157-164.

ACAMPORA, D., GULISANO, M., BROCCOLI, V. and SIMEONE, A. (2001). Otx genes in brain morphogenesis. Prog Neurobiol, 64: 69-95.

ACAMPORA, D., MAZAN, S., LALLEMAND, Y., AVANTAGGIATO, V., MAURY, M., SIMEONE, A. and BRULET, P. (1995). Forebrain and midbrain regions are deleted in Otx2-/- mutants due to a defective anterior neuroectoderm specification during gastrulation. Development, 121: 3279-3290.

AHRENS, K. and SCHLOSSER, G. (2005). Tissues and signals involved in the induction of placodal Six1 expression in Xenopus laevis. Dev Biol, 288: 40-59.

AKIMENKO, M. A., EKKER, M., WEGNER, J., LIN, W. and WESTERFIELD, M. (1994). Combinatorial expression of three zebrafish genes related to distal-less: 
part of a homeobox gene code for the head. J Neurosci, 14: 3475-3486.

AYBAR, M. J. and MAYOR, R. (2002). Early induction of neural crest cells: lessons learned from frog, fish and chick. Curr Opin Genet Dev, 12: 452-458.

AZUMA, N., HIRAKIYAMA, A., INOUE, T., ASAKA, A. and YAMADA, M. (2000). Mutations of a human homologue of the Drosophila eyes absent gene (EYA1) detected in patients with congenital cataracts and ocular anterior segment anomalies. Hum Mol Genet, 9: 363-366.

BAILEY, A. P., BHATTACHARYYA, S., BRONNER-FRASER, M. and STREIT, A. (2006). Lens is the ground state for all sensory placodes, from which FGF signalling promotes olfactory fate. Dev. Cell, 11: 505-517.

BAILEY, A. P. and STREIT, A.: Sensory organs: making and breaking the preplacodal region. In: Curr Top Dev Biol. vol. 72; 2006: 167-204

BAKER, C. V. and BRONNER-FRASER, M. (2001). Vertebrate cranial placodes I. Embryonic induction. Dev Biol, 232: 1-61.

BALLY-CUIF, L., GULISANO, M., BROCCOLI, V. and BONCINELLI, E. (1995). cotx2 is expressed in two different phases of gastrulation and is sensitive to retinoic acid treatment in chick embryo. Mech Dev, 49: 49-63.

BANCROFT, M. and BELLAIRS, R. (1977). Placodes of the chick embryo studied by SEM. Anat Embryol (Berl), 151: 97-108.

BANG, A. G., PAPALOPULU, N., KINTNER, C. and GOULDING, M. D. (1997). Expression of $\mathrm{Pax}-3$ is initiated in the early neural plate by posteriorizing signals produced by the organizer and by posterior non-axial mesoderm. Development, 124: 2075-2085.

BARTH, K. A., KISHIMOTO, Y., ROHR, K. B., SEYDLER, C., SCHULTE-MERKER, S. and WILSON, S. W. (1999). BMP activity establishes a gradient of positional information throughout the entire neural plate. Development, 126: 4977-4987.

BATEMAN, J. B., RICHTER, L., FLODMAN, P., BURCH, D., BROWN, S., PENROSE, P., PAUL, O., GEYER, D. D., BROOKS, D. G. and SPENCE, M. A. (2006). A new locus for autosomal dominant cataract on chromosome 19: linkage analyses and screening of candidate genes. Invest Ophthalmol Vis Sci, 47: 3441-3449.

BELLEFROID, E. J., KOBBE, A., GRUSS, P., PIELER, T., GURDON, J. B. and PAPALOPULU, N. (1998). Xiro3 encodes a Xenopus homolog of the Drosophila Iroquois genes and functions in neural specification. EMBO J, 17: 191-203.

BESSARAB, D. A., CHONG, S. W. and KORZH, V. (2004). Expression of zebrafish six1 during sensory organ development and myogenesis. Dev Dyn, 230: 781786.

BHATTACHARYYA, S., BAILEY, A. P., BRONNER-FRASER, M. and STREIT, A. (2004). Segregation of lens and olfactory precursors from a common territory: cell sorting and reciprocity of DIx5 and Pax6 expression. Dev Biol, 271: 403-414.

BONINI, N. M., BUI, Q. T., GRAY-BOARD, G. L. and WARRICK, J. M. (1997). The Drosophila eyes absent gene directs ectopic eye formation in a pathway conserved between flies and vertebrates. Development, 124: 4819-4826.

BONINI, N. M., LEISERSON, W. M. and BENZER, S. (1993). The eyes absent gene: genetic control of cell survival and differentiation in the developing Drosophila eye. Cell, 72: 379-395.

BRICAUD, O. and COLLAZO, A. (2006). The transcription factor six1 inhibits neuronal and promotes hair cell fate in the developing zebrafish (Danio rerio) inner ear. JNeurosci, 26: 10438-10451.

BROCCOLI, V., BONCINELLI, E. and WURST, W. (1999). The caudal limit of Otx2 expression positions the isthmic organizer. Nature, 401: 164-168.

BRUGMANN, S. A., PANDUR, P. D., KENYON, K. L., PIGNONI, F. and MOODY, S. A. (2004). Six1 promotes a placodal fate within the lateral neurogenic ectoderm by functioning as both a transcriptional activator and repressor. Development, 131: 5871-5881.

BUI, Q. T., ZIMMERMAN, J. E., LIU, H., GRAY-BOARD, G. L. and BONINI, N. M. (2000). Functional analysis of an eye enhancer of the Drosophila eyes absent gene: differential regulation by eye specification genes. Dev Biol, 221:355-364.

BURTON, Q., COLE, L. K., MULHEISEN, M., CHANG, W. and WU, D. K. (2004). The role of Pax2 in mouse inner ear development. Dev Biol, 272: 161-175.

CARPENTER, E. (1937). The head pattern in Ambystoma studied by vital staining and transplantation methods. J Exp Zool, 75: 103-129.

CHEN, R., AMOUI, M., ZHANG, Z. and MARDON, G. (1997). Dachshund and eyes absent proteins form a complex and function synergistically to induce ectopic eye development in Drosophila. Cell, 91: 893-903.

CHEYETTE, B. N., GREEN, P. J., MARTIN, K., GARREN, H., HARTENSTEIN, V. and ZIPURSKY, S. L. (1994). The Drosophila sine oculis locus encodes a homeodomain-containing protein required for the development of the entire visual system. Neuron, 12: 977-996.

CLARK, S. W., FEE, B. E. and CLEVELAND, J. L. (2002). Misexpression of the eyes absent family triggers the apoptotic program. J Biol Chem, 277: 3560-3567.

COLETTA, R. D., CHRISTENSEN, K., REICHENBERGER, K. J., LAMB, J., MICOMONACO, D., HUANG, L., WOLF, D. M., MULLER-TIDOW, C., GOLUB, T. R., KAWAKAMI, K. et al. (2004). The Six1 homeoprotein stimulates tumorigenesis by reactivation of cyclin A1. Proc NatlAcad SciUS A, 101: 6478-6483.

COULY, G. and LE DOUARIN, N. M. (1988). The fate map of the cephalic neural primordium at the presomitic to the 3-somite stage in the avian embryo. Development, 103: 101-113.

COULY, G. F. and LE DOUARIN, N. M. (1985). Mapping of the early neural primordium in quail-chick chimeras. I. Developmental relationships between placodes, facial ectoderm and prosencephalon. Dev Biol, 110: 422-439.

COULY, G. F. and LE DOUARIN, N. M. (1987). Mapping of the early neural primordium in quail-chick chimeras. II. The prosencephalic neural plate and neural folds: implications for the genesis of cephalic human congenital abnormalities. Dev Biol, 120: 198-214.

D'AMICO-MARTEL, A. and NODEN, D. M. (1983). Contributions of placodal and neural crest cells to avian cranial peripheral ganglia. Am J Anat, 166: 445-468.

DAVIS, R. J., SHEN, W., HEANUE, T. A. and MARDON, G. (1999). Mouse Dach, a homologue of Drosophila dachshund, is expressed in the developing retina, brain and limbs. Dev Genes Evol, 209: 526-536.

DONNER, A. L. and MAAS, R. L. (2004). Conservation and non-conservation of genetic pathways in eye specification. Int J Dev Biol, 48: 743-753.

DUTTA, S., DIETRICH, J. E., ASPOCK, G., BURDINE, R. D., SCHIER, A., WESTERFIELD, M. and VARGA, Z. M. (2005). pitx3 defines an equivalence domain for lens and anterior pituitary placode. Development. 1579-1590.

ESTEVE, P. and BOVOLENTA, P. (1999). cSix4, a member of the six gene family of transcription factors, is expressed during placode and somite development. Mech Dev, 85: 161-165.

FAINSOD, A., STEINBEISSER, H. and DE ROBERTIS, E. M. (1994). On the function of BMP-4 in patterning the marginal zone of the Xenopus embryo. EMBO J, 13: 5015-5025.

FAURE, S., DE SANTA BARBARA, P., ROBERTS, D. J. and WHITMAN, M. (2002). Endogenous patterns of BMP signaling during early chick development. Dev Biol, 244: 44-65

FELEDY, J. A., BEANAN, M. J., SANDOVAL, J. J., GOODRICH, J. S., LIM, J. H., MATSUO-TAKASAKI, M., SATO, S. M. and SARGENT, T. D. (1999). Inhibitory patterning of the anterior neural plate in Xenopus by homeodomain factors DIX3 and Msx1. Dev Biol, 212: 455-464.

FERNANDEZ-GARRE, P., RODRIGUEZ-GALLARDO, L., ALVAREZ, I. S. and PUELLES, L. (2002). A neural plate fate map at stage $\mathrm{HH} 4$ in the chick: methodology and preliminary data. Brain Res Bull, 57: 293-295.

FRIEDMAN, R. A., MAKMURA, L., BIESIADA, E., WANG, X. and KEITHLEY, E. M (2005). Eya1 acts upstream of Tbx1, Neurogenin 1, NeuroD and the neurotrophins BDNF and NT-3 during inner ear development. Mech Dev, 122: 625-634.

GARCIA-CASTRO, M. I., MARCELLE, C. and BRONNER-FRASER, M. (2002). Ectodermal Wnt function as a neural crest inducer. Science, 297: 848-851.

GARCIA-MARTINEZ, V., ALVAREZ, I. S. and SCHOENWOLF, G. C. (1993). Locations of the ectodermal and nonectodermal subdivisions of the epiblast at stages 3 and 4 of avian gastrulation and neurulation. J Exp Zool, 267: 431-446.

GLAVIC, A., GOMEZ-SKARMETA, J. L. and MAYOR, R. (2002). The homeoprotein Xiro1 is required for midbrain-hindbrain boundary formation. Development, 129: 1609-1621.

GLAVIC, A., MARIS HONORE, S., GLORIA FEIJOO, C., BASTIDAS, F., ALLENDE, M. L. and MAYOR, R. (2004). Role of BMP signaling and the homeoprotein Iroquois in the specification of the cranial placodal field. Dev Biol, 272: 89-103.

GOGOI, R. N., SCHUBERT, F. R., MARTINEZ-BARBERA, J.-P., ACAMPORA, D., SIMEONE, A. and LUMSDEN, A. (2002). The paired-type homeobox gene Dmbx1 marks the midbrain and pretectum. Mech. Dev. 114: 213-217.

GOMEZ-SKARMETA, J. L., GLAVIC, A., DE LA CALLE-MUSTIENES, E., MODOLELL, J. and MAYOR, R. (1998). Xiro, a Xenopus homolog of the Drosophila Iroquois complex genes, controls development at the neural plate. EMBO J, 17: 181-190 
GORIELY, A., DIEZ DEL CORRAL, R. and STOREY, K. G. (1999). c-Irx2 expression reveals an early subdivision of the neural plate in the chick embryo. Mech Dev, 87: 203-206.

GRIFONE, R., DEMIGNON, J., GIORDANI, J., NIRO, C., SOUIL, E., BERTIN, F., LACLEF, C., XU, P. X. and MAIRE, P. (2007). Eya1 and Eya2 proteins are required for hypaxial somitic myogenesis in the mouse embryo. Dev Biol, 302: 602-616.

GRIFONE, R., DEMIGNON, J., HOUBRON, C., SOUIL, E., NIRO, C., SELLER, M. J., HAMARD, G. and MAIRE, P. (2005). Six1 and Six4 homeoproteins are required for $\mathrm{Pax} 3$ and Mrf expression during myogenesis in the mouse embryo. Development, 132: 2235-2249.

GRINDLEY, J. C., HARGETT, L. K., HILL, R. E., ROSS, A. and HOGAN, B. L. (1997). Disruption of PAX6 function in mice homozygous for the Pax6Sey-1Neu mutation produces abnormalities in the early development and regionalization of the diencephalon. Mech Dev, 64: 111-126.

GROVES, A. K. and BRONNER-FRASER, M. (2000). Competence, specification and commitment in otic placode induction. Development, 127: 3489-3499.

HADDON, C. and LEWIS, J. (1996). Early ear development in the embryo of the zebrafish, Danio rerio. J Comp Neurol, 365: 113-128.

HALDER, G., CALLAERTS, P., FLISTER, S., WALLDORF, U., KLOTER, U. and GEHRING, W. J. (1998). Eyeless initiates the expression of both sine oculis and eyes absent during Drosophila compound eye development. Development, 125: 2181-2191.

HALDER, G., CALLAERTS, P. and GEHRING, W. J. (1995). Induction of ectopic eyes by targeted expression of the eyeless gene in Drosophila. Science, 267: 1788-1792.

HAMMOND, K. L., HANSON, I. M., BROWN, A. G., LETTICE, L. A. and HILL, R. E. (1998). Mammalian and Drosophila dachshund genes are related to the Ski proto-oncogene and are expressed in eye and limb. Mech Dev, 74: 121-131.

HANS, S., CHRISTISON, J., LIU, D. and WESTERFIELD, M. (2007). FGFdependent otic induction requires competence provided by Foxil and DIx3b. BMC Dev Biol, 7: 5 .

HANS, S., LIU, D. and WESTERFIELD, M. (2004). Pax8 and Pax2a function synergistically in otic specification, downstream of the Foxil and DIx3b transcription factors. Development, 131: 5091-5102.

HANSON, I. M. (2001). Mammalian homologues of the Drosophila eye specification genes. Semin Cell Dev Biol, 12: 475-484.

HATADA, Y. and STERN, C. D. (1994). A fate map of the epiblast of the early chick embryo. Development, 120: 2879-2889.

HEANUE, T. A., RESHEF, R., DAVIS, R. J., MARDON, G., OLIVER, G., TOMAREV, S., LASSAR, A. B. and TABIN, C. J. (1999). Synergistic regulation of vertebrate muscle development by Dach2, Eya2 and Six1, homologs of genes required for Drosophila eye formation. Genes Dev, 13: 3231-3243.

HEISENBERG, C. P., HOUART, C., TAKE-UCHI, M., RAUCH, G. J., YOUNG, N., COUTINHO, P., MASAI, I., CANEPARO, L., CONCHA, M. L., GEISLER, R. et al. (2001). A mutation in the Gsk3-binding domain of zebrafish Masterblind/ Axin1 leads to a fate transformation of telencephalon and eyes to diencephalon. Genes Dev, 15: 1427-1434.

HELLER, N. and BRANDLI, A. W. (1999). Xenopus Pax-2/5/8 orthologues: novel insights into Pax gene evolution and identification of Pax- 8 as the earliest marker for otic and pronephric cell lineages. Dev Genet, 24: 208-219.

HERZOG, W., SONNTAG, C., VON DER HARDT, S., ROEHL, H. H., VARGA, Z. M. and HAMMERSCHMIDT, M. (2004). FGF3 signaling from the ventral diencephalon is required for early specification and subsequent survival of the zebrafish adenohypophysis. Development, 131: 3681-3692.

HIDALGO-SANCHEZ, M., MILLET, S., BLOCH-GALLEGO, E. and ALVARADOMALLART, R. M. (2005). Specification of the meso-isthmo-cerebellar region: the Otx2/Gbx2 boundary. Brain Res Brain Res Rev, 49: 134-149.

HIRSCH, N. and HARRIS, W. A. (1997). Xenopus Pax-6 and retinal development. $\checkmark$ Neurobiol, 32: 45-61.

HOCHGREB, T., LINHARES, V. L., MENEZES, D. C., SAMPAIO, A. C., YAN, C. Y., CARDOSO, W. V., ROSENTHAL, N. and XAVIER-NETO, J. (2003). A caudorostral wave of RALDH2 conveys anteroposterior information to the cardiac field. Development, 130: 5363-5374.

HOGAN, B. L., HIRST, E. M., HORSBURGH, G. and HETHERINGTON, C. M. (1988). Small eye (Sey): a mouse model for the genetic analysis of craniofacial abnormalities. Development, 103: 115-119.

HOSKINS, B. E., CRAMER, C. H., SILVIUS, D., ZOU, D., RAYMOND, R. M., ORTEN, D. J., KIMBERLING, W. J., SMITH, R. J., WEIL, D., PETIT, C. et al (2007). Transcription Factor SIX5 Is Mutated in Patients with Branchio-OtoRenal Syndrome. Am J Hum Genet, 80: 800-804.

HUME, C. R. and DODD, J. (1993). Cwnt-8C: a novel Wnt gene with a potential role in primitive streak formation and hindbrain organization. Development, 119: 1147-1160.

IKEDA, K., WATANABE, Y., OHTO, H. and KAWAKAMI, K. (2002). Molecular interaction and synergistic activation of a promoter by Six, Eya and Dach proteins mediated through CREB binding protein. Mo/ Cel/ Biol, 22: 6759-6766.

JACOBSON, A. G. (1963). The determination and positioning of the nose, lens and ear. III. Effects of reversing the antero-posterior axis of epidermis, neural plate and neural fold. J Exp Zool, 154: 293-303.

JOHNSON, K. R., COOK, S. A., ERWAY, L. C., MATTHEWS, A. N., SANFORD, L. P., PARADIES, N. E. and FRIEDMAN, R. A. (1999). Inner ear and kidney anomalies caused by IAP insertion in an intron of the Eya1 gene in a mouse model of BOR syndrome. Hum Mol Genet, 8: 645-653.

KAJI, T. and ARTINGER, K. B. (2004). dlx3b and dlx4b function in the development of Rohon-Beard sensory neurons and trigeminal placode in the zebrafish neurula. Dev Biol, 276: 523-540.

KATAHIRA, T., SATO, T., SUGIYAMA, S., OKAFUJI, T., ARAKI, I., FUNAHASHI, J. and NAKAMURA, H. (2000). Interaction between Otx2 and Gbx2 defines the organizing center for the optic tectum. Mech Dev, 91: 43-52.

KAWAKAMI, K., SATO, S., OZAKI, H. and IKEDA, K. (2000). Six family genes structure and function as transcription factors and their roles in development. Bioessays, 22: 616-626.

KELLER, R. and TIBBETTS, P. (1989). Mediolateral cell intercalation in the dorsal, axial mesoderm of Xenopus laevis. Dev Biol, 131: 539-549.

KELLER, R. E. (1975). Vital dye mapping of the gastrula and neurula of Xenopus laevis. I. Prospective areas and morphogenetic movements of the superficial layer. Dev Biol, 42: 222-241.

KELLER, R. E. (1976). Vital dye mapping of the gastrula and neurula of Xenopus laevis. II. Prospective areas and morphogenetic movements of the deep layer. Dev Biol, 51: 118-137.

KHADKA, D., LUO, T. and SARGENT, T. D. (2006). Msx1 and Msx2 have shared essential functions in neural crest but may be dispensable in epidermis and axis formation in Xenopus. Int J Dev Biol, 50: 499-502.

KIDA, Y., MAEDA, Y., SHIRAISHI, T., SUZUKI, T. and OGURA, T. (2004). Chick Dach1 interacts with the Smad complex and Sin3a to control AER formation and limb development along the proximodistal axis. Development, 131: 4179-4187.

KIECKER, C. and LUMSDEN, A. (2005). Compartments and their boundaries in vertebrate brain development. Nat Rev Neurosci, 6: 553-564.

KIM, C. H., ODA, T., ITOH, M., JIANG, D., ARTINGER, K. B. CHANDRASEKHARAPPA, S. C., DRIEVER, W. and CHITNIS, A. B. (2000). Repressor activity of Headless/Tcf3 is essential for vertebrate head formation. Nature, 407: 913-916.

KIMMEL, C. B. and WARGA, R. M. (1988). Cell lineage and developmental potential of cells in the zebrafish embryo. Trends Genet, 4: 68-74.

KIMMEL, C. B., WARGA, R. M. and SCHILLING, T. F. (1990). Origin and organization of the zebrafish fate map. Development, 108: 581-594.

KISHI, M., MIZUSEKI, K., SASAI, N., YAMAZAKI, H., SHIOTA, K., NAKANISHI, S. and SASAI, Y. (2000). Requirement of Sox2-mediated signaling for differentiation of early Xenopus neuroectoderm. Development, 127: 791-800.

KLESERT, T. R., CHO, D. H., CLARK, J. I., MAYLIE, J., ADELMAN, J., SNIDER L., YUEN, E. C., SORIANO, P. and TAPSCOTT, S. J. (2000). Mice deficient in Six 5 develop cataracts: implications for myotonic dystrophy. Nat Genet, 25: 105-109.

KNECHT, A. K. and BRONNER-FRASER, M. (2002). Induction of the neural crest: a multigene process. Nat Rev Genet, 3: 453-461.

KOBAYASHI, D., KOBAYASHI, M., MATSUMOTO, K., OGURA, T., NAKAFUKU, M. and SHIMAMURA, K. (2002). Early subdivisions in the neural plate define distinct competence for inductive signals. Development, 129: 83-93.

KOBAYASHI, H., KAWAKAMI, K., ASASHIMA, M. and NISHINAKAMURA, R. (2007). Six1 and Six4 are essential for Gdnf expression in the metanephric 
mesenchyme and ureteric bud formation, while Six 1 deficiency alone causes mesonephric-tubule defects. Mech Dev, 124: 290-303.

KOBAYASHI, M., NISHIKAWA, K., SUZUKI, T. and YAMAMOTO, M. (2001). The homeobox protein Six3 interacts with the Groucho corepressor and acts as a transcriptional repressor in eye and forebrain formation. Dev Biol, 232: 315-326.

KOBAYASHI, M., OSANAI, H., KAWAKAMI, K. and YAMAMOTO, M. (2000). Expression of three zebrafish Six4 genes in the cranial sensory placodes and the developing somites. Mech Dev, 98: 151-155.

KONISHI, Y., IKEDA, K., IWAKURA, Y. and KAWAKAMI, K. (2006). Six1 and Six4 promote survival of sensory neurons during early trigeminal gangliogenesis. Brain Res, 1116: 93-102.

KOZLOWSKI, D. J., MURAKAMI, T., HO, R. K. and WEINBERG, E. S. (1997). Regional cell movement and tissue patterning in the zebrafish embryo revealed by fate mapping with caged fluorescein. Biochem Cel/ Biol, 75: 551-562.

KOZLOWSKI, D. J., WHITFIELD, T. T., HUKRIEDE, N. A., LAM, W. K. and WEINBERG, E. S. (2005). The zebrafish dog-eared mutation disrupts eya1, a gene required for cell survival and differentiation in the inner ear and lateral line. Dev Biol, 277: 27-41

KROLL, K. L., SALIC, A. N., EVANS, L. M. and KIRSCHNER, M. W. (1998). Geminin, a neuralizing molecule that demarcates the future neural plate at the onset of gastrulation. Development, 125: 3247-3258.

KUDOH, T., CONCHA, M. L., HOUART, C., DAWID, I. B. and WILSON, S. W. (2004). Combinatorial FGF and BMP signalling patterns the gastrula ectoderm into prospective neural and epidermal domains. Development, 131:3581-3592.

KUMAR, J. P. and MOSES, K. (2001). Eye specification in Drosophila: perspectives and implications. Semin Cell Dev Biol, 12: 469-474.

LABONNE, C. and BRONNER-FRASER, M. (1998). Neural crest induction in Xenopus: evidence for a two-signal model. Development, 125: 2403-2414.

LACLEF, C., SOUIL, E., DEMIGNON, J. and MAIRE, P. (2003). Thymus, kidney and craniofacial abnormalities in Six 1 deficient mice. Mech Dev, 120: 669-679.

LADHER, R. K., ANAKWE, K. U., GURNEY, A. L., SCHOENWOLF, G. C. and FRANCIS-WEST, P. H. (2000). Identification of synergistic signals initiating inner ear development. Science, 290: 1965-1968.

LAGUTIN, O. V., ZHU, C. C., KOBAYASHI, D., TOPCZEWSKI, J., SHIMAMURA, K., PUELLES, L., RUSSELL, H. R., MCKINNON, P. J., SOLNICA-KREZEL, L. and OLIVER, G. (2003). Six3 repression of Wnt signaling in the anterior neuroectoderm is essential for vertebrate forebrain development. Genes Dev, 17: 368-379.

LAWSON, K. A. (1999). Fate mapping the mouse embryo. Int J Dev Biol, 43: 773775.

LEE, S. A., SHEN, E. L., FISER, A., SALI, A. and GUO, S. (2003). The zebrafish forkhead transcription factor Foxil specifies epibranchial placode-derived sensory neurons. Development, 130: 2669-2679.

LEGER, S. and BRAND, M. (2002). FGF8 and FGF3 are required for zebrafish ear placode induction, maintenance and inner ear patterning. Mech Dev, 119: 91 108.

LI, H. S., YANG, J. M., JACOBSON, R. D., PASKO, D. and SUNDIN, O. (1994). Pax6 is first expressed in a region of ectoderm anterior to the early neural plate: implications for stepwise determination of the lens. Dev Biol, 162: 181-194.

LI, J. Y. and JOYNER, A. L. (2001). Otx2 and Gbx2 are required for refinement and not induction of mid-hindbrain gene expression. Development, 128: 4979-4991.

LI, X., OGHI, K. A., ZHANG, J., KRONES, A., BUSH, K. T., GLASS, C. K., NIGAM, S. K., AGGARWAL, A. K., MAAS, R., ROSE, D. W. et al. (2003). Eya protein phosphatase activity regulates Six1-Dach-Eya transcriptional effects in mammalian organogenesis. Nature, 426: 247-254.

LIEM, K. F., JR., TREMML, G., ROELINK, H. and JESSELL, T. M. (1995). Dorsal differentiation of neural plate cells induced by BMP-mediated signals from epidermal ectoderm. Cell, 82: 969-979.

LIN, Z., CANTOS, R., PATENTE, M. and WU, D. K. (2005). Gbx2 is required for the morphogenesis of the mouse inner ear: a downstream candidate of hindbrain signaling. Development, 132: 2309-2318.

LITSIOU, A., HANSON, S. and STREIT, A. (2005). A balance of FGF, Wnt and BMP signalling positions the future placode territory in the head. Development, 132 4051-4062.

LIU, D., CHU, H., MAVES, L., YAN, Y. L., MORCOS, P. A., POSTLETHWAIT, J. H. and WESTERFIELD, M. (2003). FGF3 and FGF8 dependent and independent transcription factors are required for otic placode specification. Development, 130: 2213-2224.

LIU, W., LAGUTIN, O. V., MENDE, M., STREIT, A. and OLIVER, G. (2006). Six3 activation of Pax6 expression is essential for mammalian lens induction and specification. EMBO J, 25: 5383-5395.

LUO, T., MATSUO-TAKASAKI, M., LIM, J. H. and SARGENT, T. D. (2001). Differential regulation of DIx gene expression by a BMP morphogenetic gradient. Int J Dev Biol, 45: 681-684.

LUO, T., MATSUO-TAKASAKI, M. and SARGENT, T. D. (2001). Distinct roles for Distal-less genes DIX3 and DIX5 in regulating ectodermal development in Xenopus. Mol Reprod Dev, 60: 331-337.

MARCHANT, L., LINKER, C., RUIZ, P., GUERRERO, N. and MAYOR, R. (1998). The inductive properties of mesoderm suggest that the neural crest cells are specified by a BMP gradient. Dev Biol, 198: 319-329.

MARDON, G., SOLOMON, N. M. and RUBIN, G. M. (1994). dachshund encodes a nuclear protein required for normal eye and leg development in Drosophila. Development, 120: 3473-3486.

MAROON, H., WALSHE, J., MAHMOOD, R., KIEFER, P., DICKSON, C. and MASON, I. (2002). FGF3 and FGF8 are required together for formation of the otic placode and vesicle. Development, 129: 2099-2108.

MARTIN, K. and GROVES, A. K. (2006). Competence of cranial ectoderm to respond to FGF signaling suggests a two-step model of otic placode induction. Development, 133: 877-887.

MARTINEZ, S. (2001). The isthmic organizer and brain regionalization. Int J Dev Biol, 45: 367-371.

MATSUMOTO, K., NISHIHARA, S., KAMIMURA, M., SHIRAISHI, T., OTOGURO, T., UEHARA, M., MAEDA, Y., OGURA, K., LUMSDEN, A. and OGURA, T. (2004). The prepattern transcription factor Irx2, a target of the FGF8/MAP kinase cascade, is involved in cerebellum formation. Nat Neurosci, 7: 605-612

MATSUNAGA, E., ARAKI, I. and NAKAMURA, H. (2000). Pax6 defines the dimesencephalic boundary by repressing En1 and Pax2. Development, 127 2357-2365.

MATSUO-TAKASAKI, M., MATSUMURA, M. and SASAI, Y. (2005). An essential role of Xenopus Foxila for ventral specification of the cephalic ectoderm during gastrulation. Development, 132: 3885-3894

MAYOR, R., GUERRERO, N. and MARTINEZ, C. (1997). Role of FGF and noggin in neural crest induction. Dev Biol, 189: 1-12.

MCLARREN, K. W., LITSIOU, A. and STREIT, A. (2003). DLX5 positions the neural crest and preplacode region at the border of the neural plate. Dev Biol, 259: 3447.

MEULEMANS, D. and BRONNER-FRASER, M. (2004). Gene-regulatory interactions in neural crest evolution and development. Dev Cell, 7: 291-299.

MILLET, S., CAMPBELL, K., EPSTEIN, D. J., LOSOS, K., HARRIS, E. and JOYNER, A. L. (1999). A role for Gbx2 in repression of Otx2 and positioning the $\mathrm{mid} /$ hindbrain organizer. Nature, 401: 161-164.

MISHIMA, N. and TOMAREV, S. (1998). Chicken Eyes absent 2 gene: isolation and expression pattern during development. Int J Dev Biol, 42: 1109-1115.

MIZUSEKI, K., KISHI, M., SHIOTA, K., NAKANISHI, S. and SASAI, Y. (1998). SoxD: an essential mediator of induction of anterior neural tissues in Xenopus embryos. Neuron, 21: 77-85.

MONSORO-BURQ, A. H., FLETCHER, R. B. and HARLAND, R. M. (2003). Neural crest induction by paraxial mesoderm in Xenopus embryos requires FGF signals. Development, 130: 3111-3124.

MONSORO-BURQ, A. H., WANG, E. and HARLAND, R. (2005). Msx1 and Pax3 cooperate to mediate FGF8 and WNT signals during Xenopus neural cres induction. Dev Cell, 8: 167-178.

NAKAMURA, H. (2001). Regionalization of the optic tectum: combinations of gene expression that define the tectum. Trends Neurosci, 24: 32-39.

NEAVE, B., HOLDER, N. and PATIENT, R. (1997). A graded response to BMP-4 spatially coordinates patterning of the mesoderm and ectoderm in the zebrafish. Mech Dev, 62: 183-195.

NECHIPORUK, A., LINBO, T., POSS, K. D. and RAIBLE, D. W. (2007). Specification of epibranchial placodes in zebrafish. Development, 134: 611-623.

NGUYEN, V. H., SCHMID, B., TROUT, J., CONNORS, S. A., EKKER, M. and 
MULLINS, M. C. (1998). Ventral and lateral regions of the zebrafish gastrula, including the neural crest progenitors, are established by a bmp2b/swirl pathway of genes. Dev Biol, 199: 93-110.

NIIMI, T., SEIMIYA, M., KLOTER, U., FLISTER, S. and GEHRING, W. J. (1999). Direct regulatory interaction of the eyeless protein with an eye-specific enhancer in the sine oculis gene during eye induction in Drosophila. Development, 126: 2253-2260.

NIKAIDO, M., DOI, K., SHIMIZU, T., HIBI, M., KIKUCHI, Y. and YAMASU, K. (2007). Initial specification of the epibranchial placode in zebrafish embryos depends on the fibroblast growth factor signal. Dev Dyn, 236: 564-571.

NISSEN, R. M., YAN, J., AMSTERDAM, A., HOPKINS, N. and BURGESS, S. M. (2003). Zebrafish foxi one modulates cellular responses to FGF signaling required for the integrity of ear and jaw patterning. Development, 130: 25432554.

NISWANDER, L. and MARTIN, G. R. (1992). FGF-4 expression during gastrulation, myogenesis, limb and tooth development in the mouse. Development, 114: 755 768.

OGITA, J., ISOGAI, E., SUDO, H., SAKIYAMA, S., NAKAGAWARA, A. and KOSEKI, H. (2001). Expression of the Dan gene during chicken embryonic development. Mech Dev, 109: 363-365.

OHTO, H., KAMADA, S., TAGO, K., TOMINAGA, S. I., OZAKI, H., SATO, S. and KAWAKAMI, K. (1999). Cooperation of six and eya in activation of their target genes through nuclear translocation of Eya. Mol Cell Biol, 19: 6815-6824.

OHYAMA, T. and GROVES, A. K. (2004). Expression of mouse Foxi class genes in early craniofacial development. Dev Dyn, 231: 640-646.

OHYAMA, T., MOHAMED, O. A., TAKETO, M. M., DUFORT, D. and GROVES, A. K. (2006). Wnt signals mediate a fate decision between otic placode and epidermis. Development, 133: 865-875.

OKAFUJI, T., FUNAHASHI, J. and NAKAMURA, H. (1999). Roles of Pax-2 in initiation of the chick tectal development. Brain Res Dev Brain Res, 116: 41-49.

OLIVER, G., MAILHOS, A., WEHR, R., COPELAND, N. G., JENKINS, N. A. and GRUSS, P. (1995). Six3, a murine homologue of the sine oculis gene, demarcates the most anterior border of the developing neural plate and is expressed during eye development. Development, 121: 4045-4055.

OZAKI, H., NAKAMURA, K., FUNAHASHI, J., IKEDA, K., YAMADA, G., TOKANO, H., OKAMURA, H. O., KITAMURA, K., MUTO, S., KOTAKI, H. etal. (2004). Six1 controls patterning of the mouse otic vesicle. Development, 131: 551-562.

OZAKI, H., WATANABE, Y., TAKAHASHI, K., KITAMURA, K., TANAKA, A. URASE, K., MOMOI, T., SUDO, K., SAKAGAMI, J., ASANO, M. et al. (2001). Six4, a putative myogenin gene regulator, is not essential for mouse embryonal development. Mol Cel/ Biol, 21: 3343-3350.

PANDUR, P. D. and MOODY, S. A. (2000). Xenopus Six1 gene is expressed in neurogenic cranial placodes and maintained in the differentiating lateral lines. Mech Dev, 96: 253-257.

PANNESE, M., POLO, C., ANDREAZZOLI, M., VIGNALI, R., KABLAR, B. BARSACCHI, G. and BONCINELLI, E. (1995). The Xenopus homologue of Otx2 is a maternal homeobox gene that demarcates and specifies anterior body regions. Development, 121: 707-720.

PAPALOPULU, N. and KINTNER, C. (1993). Xenopus Distal-less related homeobox genes are expressed in the developing forebrain and are induced by planar signals. Development, 117: 961-975.

PAPPU, K. S. and MARDON, G. (2004). Genetic control of retinal specification and determination in Drosophila. Int J Dev Biol, 48: 913-924.

PAPPU, K. S., OSTRIN, E. J., MIDDLEBROOKS, B. W., SILI, B. T., CHEN, R., ATKINS, M. R., GIBBS, R. and MARDON, G. (2005). Dual regulation and redundant function of two eye-specific enhancers of the Drosophila retinal determination gene dachshund. Development, 132: 2895-2905.

PENZEL, R., OSCHWALD, R., CHEN, Y., TACKE, L. and GRUNZ, H. (1997). Characterization and early embryonic expression of a neural specific transcription factor xSOX3 in Xenopus laevis. Int J Dev Biol, 41: 667-677.

PERA, E., STEIN, S. and KESSEL, M. (1999). Ectodermal patterning in the avian embryo: epidermis versus neural plate. Development, 126: 63-73.

PHILLIPS, B. T., KWON, H. J., MELTON, C., HOUGHTALING, P., FRITZ, A. and RILEY, B. B. (2006). Zebrafish $m s x B, m s x C$ and $m s x E$ function together to refine the neural-nonneural border and regulate cranial placodes and neural crest development. Dev Biol, 294: 376-390.
PIGNONI, F., HU, B., ZAVITZ, K. H., XIAO, J., GARRITY, P. A. and ZIPURSKY, S L. (1997). The eye-specification proteins So and Eya form a complex and regulate multiple steps in Drosophila eye development [published erratum appears in Cell $1998 \mathrm{Feb}$ 20;92(4):following 585]. Cell, 91: 881-891.

PUNZO, C., SEIMIYA, M., FLISTER, S., GEHRING, W. J. and PLAZA, S. (2002). Differential interactions of eyeless and twin of eyeless with the sine oculis enhancer. Development, 129: 625-634.

PURCELL, P., OLIVER, G., MARDON, G., DONNER, A. L. and MAAS, R. L. (2005). Pax6-dependence of Six3, Eya1 and Dach1 expression during lens and nasal placode induction. Gene Expr Patterns, 6: 110-118.

QUINN, J. C., WEST, J. D. and HILL, R. E. (1996). Multiple functions for Pax6 in mouse eye and nasal development. Genes Dev, 10: 435-446.

QUIRING, R., WALLDORF, U., KLOTER, U. and GEHRING, W. J. (1994). Homology of the eyeless gene of Drosophila to the Small eye gene in mice and Aniridia in humans. Science, 265: 785-789.

RAYAPUREDDI, J. P., KATTAMURI, C., STEINMETZ, B. D., FRANKFORT, B. J., OSTRIN, E. J., MARDON, G. and HEGDE, R. S. (2003). Eyes absent represents a class of protein tyrosine phosphatases. Nature, 426: 295-298.

REBAY, I., SILVER, S. J. and TOOTLE, T. L. (2005). New vision from Eyes absent: transcription factors as enzymes. Trends Genet, 21: 163-171.

REDKAR, A., MONTGOMERY, M. and LITVIN, J. (2001). Fate map of early avian cardiac progenitor cells. Development, 128: 2269-2279.

RELAIX, F. and BUCKINGHAM, M. (1999). From insect eye to vertebrate muscle: redeployment of a regulatory network. Genes Dev, 13: 3171-3178.

REX, M., ORME, A., UWANOGHO, D., TOINTON, K., WIGMORE, P. M., SHARPE, P. T. and SCOTTING, P. J. (1997). Dynamic expression of chicken Sox2 and Sox3 genes in ectoderm induced to form neural tissue. Dev Dyn, 209: 323-332.

RHINN, M., PICKER, A. and BRAND, M. (2006). Global and local mechanisms of forebrain and midbrain patterning. Curr Opin Neurobiol, 16: 5-12.

RUF, R. G., XU, P. X., SILVIUS, D., OTTO, E. A., BEEKMANN, F., MUERB, U. T. KUMAR, S., NEUHAUS, T. J., KEMPER, M. J., RAYMOND, R. M., JR. et al. (2004). SIX1 mutations cause branchio-oto-renal syndrome by disruption of EYA1-SIX1-DNA complexes. Proc Nat/ Acad Sci U S A, 101: 8090-8095.

SAHLY, I., ANDERMANN, P. and PETIT, C. (1999). The zebrafish eya1 gene and its expression pattern during embryogenesis. Dev Genes Evol, 209: 399-410.

SARKAR, P. S., APPUKUTTAN, B., HAN, J., ITO, Y., AI, C., TSAI, W., CHAI, Y., STOUT, J. T. and REDDY, S. (2000). Heterozygous loss of Six5 in mice is sufficient to cause ocular cataracts. Nat Genet, 25: 110-114.

SASAI, Y. and DE ROBERTIS, E. M. (1997). Ectodermal patterning in vertebrate embryos. Dev Biol, 182: 5-20.

SBROGNA, J. L., BARRESI, M. J. and KARLSTROM, R. O. (2003). Multiple roles for Hedgehog signaling in zebrafish pituitary development. Dev Biol, 254: 19-35.

SCHLOSSER, G. (2006). Induction and specification of cranial placodes. Dev Biol, 294: 303-305

SCHLOSSER, G. and AHRENS, K. (2004). Molecular anatomy of placode development in Xenopus laevis. Dev Biol, 271: 439-466.

SCHLOSSER, G. and NORTHCUTT, R. G. (2000). Development of neurogenic placodes in Xenopus laevis. J Comp Neurol, 418: 121-146.

SCHONBERGER, J., WANG, L., SHIN, J. T., KIM, S. D., DEPREUX, F. F., ZHU, H., ZON, L., PIZARD, A., KIM, J. B., MACRAE, C. A. et al. (2005). Mutation in the transcriptional coactivator EYA4 causes dilated cardiomyopathy and sensorineural hearing loss. Nat Genet, 37: 418-422.

SCHUBERT, F. R., MOOTOOSAMY, R. C., WALTERS, E. H., GRAHAM, A., TUMIOTTO, L., MUNSTERBERG, A. E., LUMSDEN, A. and DIETRICH, S. (2002). Wnt6 marks sites of epithelial transformations in the chick embryo. Mech Dev, 114: 143-148.

SCHWARZ, M., AlVAREZ-BOlAdo, G., DRESSleR, G., URBANEK, P., BUSSLINGER, M. and GRUSS, P. (1999). Pax2/5 and Pax6 subdivide the early neural tube into three domains. Mech Dev, 82: 29-39.

SCHWARZ, M., CECCONI, F., BERNIER, G., ANDREJEWSKI, N., KAMMANDEL, B., WAGNER, M. and GRUSS, P. (2000). Spatial specification of mammalian eye territories by reciprocal transcriptional repression of Pax2 and Pax6. Development, 127: 4325-4334.

SEO, H. C., CURTISS, J., MLODZIK, M. and FJOSE, A. (1999). Six class homeobox genes in Drosophila belong to three distinct families and are involved in head 
development. Mech Dev, 83: 127-139.

SERIKAKU, M. A. and O'TOUSA, J. E. (1994). sine oculis is a homeobox gene required for Drosophila visual system development. Genetics, 138: 1137-1150.

SHAMIM, H. and MASON, I. (1998). Expression of Gbx-2 during early development of the chick embryo. Mech Dev, 76: 157-159.

SHAMIM, H. and MASON, I. (1999). Expression of FGF4 during early development of the chick embryo. Mech Dev, 85: 189-192.

SHEN, W. and MARDON, G. (1997). Ectopic eye development in Drosophila induced by directed dachshund expression. Development, 124: 45-52.

SHENG, G. and STERN, C. D. (1999). Gata2 and Gata3: novel markers for early embryonic polarity and for non-neural ectoderm in the chick embryo. Mech Dev, 87: 213-216.

SILVER, S. J., DAVIES, E. L., DOYON, L. and REBAY, I. (2003). Functional dissection of eyes absent reveals new modes of regulation within the retinal determination gene network. Mol Cell Biol, 23: 5989-5999.

SILVER, S. J. and REBAY, I. (2005). Signaling circuitries in development: insights from the retinal determination gene network. Development, 132: 3-13.

SOLOMON, K. S. and FRITZ, A. (2002). Concerted action of two dlx paralogs in sensory placode formation. Development, 129: 3127-3136.

SOLOMON, K. S., KUDOH, T., DAWID, I. B. and FRITZ, A. (2003). Zebrafish Foxil mediates otic placode formation and jaw development. Development, 130: 929940.

SOLOMON, K. S., KWAK, S. J. and FRITZ, A. (2004). Genetic interactions underlying otic placode induction and formation. Dev Dyn, 230: 419-433.

STARK, M. R., SECHRIST, J., BRONNER-FRASER, M. and MARCELLE, C. (1997). Neural tube-ectoderm interactions are required for trigeminal placode formation. Development, 124: 4287-4295.

STERN, C. D. (2005). Neural induction: old problem, new findings, yet more questions. Development, 132: 2007-2021.

STREIT, A. (2002). Extensive cell movements accompany formation of the otic placode. Dev Biol, 249: 237-254.

STREIT, A. (2004). Early development of the cranial sensory nervous system: from a common field to individual placodes. Dev Biol, 276: 1-15.

STREIT, A., BERLINER, A. J., PAPANAYOTOU, C., SIRULNIK, A. and STERN, C. D. (2000). Initiation of neural induction by FGF signalling before gastrulation. Nature, 406: 74-78.

STREIT, A., LEE, K. J., WOO, I., ROBERTS, C., JESSELL, T. M. and STERN, C. D. (1998). Chordin regulates primitive streak development and the stability of induced neural cells, but is not sufficient for neural induction in the chick embryo. Development, 125: 507-519.

STREIT, A. and STERN, C. D. (1999). Establishment and maintenance of the border of the neural plate in the chick: involvement of FGF and BMP activity. Mech Dev, 82: 51-66.

SUN, S. K., DEE, C. T., TRIPATHI, V. B., RENGIFO, A., HIRST, C. S. and SCOTTING, P. J. (2007). Epibranchial and otic placodes are induced by a common FGF signal, but their subsequent development is independent. Dev Biol, 303: 675-686.

SUZUKI, A., UENO, N. and HEMMATI-BRIVANLOU, A. (1997). Xenopus msx1 mediates epidermal induction and neural inhibition by BMP4. Development 124: 3037-3044.

TAM, P. P. (1989). Regionalisation of the mouse embryonic ectoderm: allocation of prospective ectodermal tissues during gastrulation. Development, 107: 55-67.

TAM, P. P., PARAMESWARAN, M., KINDER, S. J. and WEINBERGER, R. P. (1997). The allocation of epiblast cells to the embryonic heart and other mesodermal lineages: the role of ingression and tissue movement during gastrulation. Development, 124: 1631-1642.

TOOTLE, T. L., SILVER, S. J., DAVIES, E. L., NEWMAN, V., LATEK, R. R., MILLS, I. A., SELENGUT, J. D., PARLIKAR, B. E. and REBAY, I. (2003). The transcription factor Eyes absent is a protein tyrosine phosphatase. Nature, 426:299-302.

TORRES, M. and GIRALDEZ, F. (1998). The development of the vertebrate inner ear. Mech Dev, 71: 5-21.

TORRES, M., GOMEZ-PARDO, E. and GRUSS, P. (1996). Pax2 contributes to inner ear patterning and optic nerve trajectory. Development, 122: 3381-3391.

TRIBULO, C., AYBAR, M. J., NGUYEN, V. H., MULLINS, M. C. and MAYOR, R.
(2003). Regulation of Msx genes by a BMP gradient is essential for neural crest specification. Development, 130: 6441-6452.

VENDRELL, V., CARNICERO, E., GIRALDEZ, F., ALONSO, M. T. and SCHIMMANG, T. (2000). Induction of inner ear fate by FGF3. Development, 127: 2011-2019.

VERWOERD, C. D., VAN OOSTROM, C. G. and VERWOERD-VERHOEF, H. L. (1981). Otic placode and cephalic neural crest. Acta Otolaryngol, 91: 431-435.

VILLANUEVA, S., GLAVIC, A., RUIZ, P. and MAYOR, R. (2002). Posteriorization by FGF, Wnt and retinoic acid is required for neural crest induction. Dev Biol, 241: 289-301.

VONICA, A. and BRIVANLOU, A. H. (2006). An obligatory caravanserai stop on the silk road to neural induction: inhibition of BMP/GDF signaling. Semin Cel/ Dev Biol, 17: 117-132.

WAWERSIK, S. and MAAS, R. L. (2000). Vertebrate eye development as modeled in Drosophila. Hum Mol Genet, 9: 917-925.

WAYNE, S., ROBERTSON, N. G., DECLAU, F., CHEN, N., VERHOEVEN, K., PRASAD, S., TRANEBJARG, L., MORTON, C. C., RYAN, A. F., VAN CAMP, G. et al. (2001). Mutations in the transcriptional activator EYA4 cause late-onset deafness at the DFNA10 locus. Hum Mol Genet, 10: 195-200.

WEASNER, B., SALZER, C. and KUMAR, J. P. (2007). Sine oculis, a member of the SIX family of transcription factors, directs eye formation. Dev Biol, 303: 756-771.

WHITFIELD, T. T. (2005). Lateral line: precocious phenotypes and planar polarity. Curr Biol, 15: R67-70.

WILSON, P. A., LAGNA, G., SUZUKI, A. and HEMMATI-BRIVANLOU, A. (1997). Concentration-dependent patterning of the Xenopus ectoderm by BMP 4 and its signal transducer Smad1. Development, 124: 3177-3184.

WILSON, S. W. and HOUART, C. (2004). Early steps in the development of the forebrain. Dev Cell, 6: 167-181.

WODA, J. M., PASTAGIA, J., MERCOLA, M. and ARTINGER, K. B. (2003). DIx proteins position the neural plate border and determine adjacent cell fates. Development, 130: 331-342.

WOO, K. and FRASER, S. E. (1995). Order and coherence in the fate map of the zebrafish nervous system. Development, 121: 2595-2609.

WRIGHT, T. J. and MANSOUR, S. L. (2003). FGF3 and FGF10 are required for mouse otic placode induction. Development, 130: 3379-3390.

WU, K., YANG, Y., WANG, C., DAVOLI, M. A., D'AMICO, M., LI, A., CVEKLOVA, K., KOZMIK, Z., LISANTI, M. P., RUSSELL, R. G. et al. (2003). DACH1 inhibits transforming growth factor-beta signaling through binding Smad4. JBio/Chem, 278: 51673-51684.

XU, P. X., ADAMS, J., PETERS, H., BROWN, M. C., HEANEY, S. and MAAS, R. (1999). Eya1-deficient mice lack ears and kidneys and show abnormal apoptosis of organ primordia. Nat Genet, 23: 113-117.

YAMAGUCHI, T. P. (2001). Heads or tails: Wnts and anterior-posterior patterning. Curr Biol, 11: R713-724.

YU, Y., DAVICIONI, E., TRICHE, T. J. and MERLINO, G. (2006). The homeoprotein six 1 transcriptionally activates multiple protumorigenic genes but requires ezrin to promote metastasis. Cancer Res, 66: 1982-1989.

ZHANG, H., HU, G., WANG, H., SCIAVOLINO, P., ILER, N., SHEN, M. M. and ABATE-SHEN, C. (1997). Heterodimerization of Msx and DIx homeoproteins results in functional antagonism. Mol Cell Biol, 17: 2920-2932.

ZHANG, L., YANG, N., HUANG, J., BUCKANOVICH, R. J., LIANG, S., BARCHETTI, A., VEZZANI, C., O'BRIEN-JENKINS, A., WANG, J., WARD, M. R. etal. (2005). Transcriptional coactivator Drosophila eyes absent homologue 2 is up-regulated in epithelial ovarian cancer and promotes tumor growth. Cancer Res, 65: 925-932.

ZHANG, Y., KNOSP, B. M., MACONOCHIE, M., FRIEDMAN, R. A. and SMITH, R. J. (2004). A comparative study of Eya1 and Eya4 protein function and its implication in branchio-oto-renal syndrome and DFNA10. J Assoc Res Otolaryngol, 5: 295-304.

ZHENG, W., HUANG, L., WEI, Z. B., SILVIUS, D., TANG, B. and XU, P. X. (2003). The role of Six1 in mammalian auditory system development. Development, 130: $3989-4000$.

ZHOU, X., HOLlEMANN, T., PIELER, T. and GRUSS, P. (2000). Cloning and expression of $x \operatorname{Six} 3$, the Xenopus homologue of murine Six3. Mech Dev, 91: 327-330.

ZHU, C. C., DYER, M. A., UCHIKAWA, M., KONDOH, H., LAGUTIN, O. V. and 
OLIVER, G. (2002). Six3-mediated auto repression and eye development requires its interaction with members of the Groucho-related family of corepressors. Development, 129: 2835-2849.

ZILINSKI, C. A., SHAH, R., LANE, M. E. and JAMRICH, M. (2005). Modulation of zebrafish pitx3 expression in the primordia of the pituitary, lens, olfactory epithelium and cranial ganglia by hedgehog and nodal signaling. Genesis, 41: 33-40.

ZOU, D., SILVIUS, D., FRITZSCH, B. and XU, P. X. (2004). Eya1 and Six1 are essential for early steps of sensory neurogenesis in mammalian cranial pla- codes. Development, 131: 5561-5572.

ZOU, D., SILVIUS, D., RODRIGO-BLOMQVIST, S., ENERBACK, S. and XU, P.-X. (2006). Eya1 regulates the growth of otic epithelium and interacts with Pax2 during the development of all sensory areas in the inner ear. Dev. Biol. 298: 430441.

\section{Related, previously published Int. J. Dev. Biol. articles}

See our Special Issue Ear Development edited by Fernando Giraldez and Bernd Fritzsch at: http://www.ijdb.ehu.es/web/contents.php?vol=51\&issue=6-7

\section{Analysis of Netrin 1 receptors during inner ear development}

Tanja Matilainen, Maarja Haugas, Jordan A. Kreidberg and Marjo Salminen

Int. J. Dev. Biol. (2007) 51: 409-414

Cell proliferation during the early compartmentalization of the Xenopus laevis inner ear Quincy A. Quick and Elba E. Serrano

Int. J. Dev. Biol. (2007) 51: 201-210

Single-cell transcriptional profiles and spatial patterning of the mammalian olfactory epithelium lan Tietjen, Jason Rihel and Catherine G. Dulac

Int. J. Dev. Biol. (2005) 49: 201-207

Functional analysis of FGF3 during zebrafish inner ear development

V Vendrell, D Gimnopoulos, T Becker, T Schimmang

Int. J. Dev. Biol. (2001) 45: S105-S106

Regulation of neural crest cell populations: occurrence, distribution and underlying mechanisms. $\mathrm{J} L$ Vaglia and B K Hall

Int. J. Dev. Biol. (1999) 43: 95-110

\section{Effects of growth factors on the differentiation of neural crest cells and} neural crest cell-derivatives.

B K Hall and S Ekanayake

Int. J. Dev. Biol. (1991) 35: 367-387 